\title{
SOUTHEASTERN EXTENSION OF SALCHA RIVER-POGO ELECTROMAGNETIC AND MAGNETIC AIRBORNE GEOPHYSICAL SURVEY DATA COMPILATION
}

Burns, L.E., Graham, G.R.C., Barefoot, J.D., Naibert, T.J., Fugro Airborne Surveys Corps., and Stevens Exploration Management Corp.

Geophysical Report 2019-9

2019

STATE OF ALASKA

DEPARTMENT OF NATURAL RESOURCES

DIVISION OF GEOLOGICAL \& GEOPHYSICAL SURVEYS
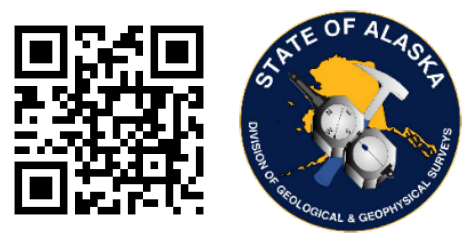
STATE OF ALASKA

Michael J. Dunleavy, Governor

DEPARTMENT OF NATURAL RESOURCES

Corri A. Feige, Commissioner

\title{
DIVISION OF GEOLOGICAL \& GEOPHYSICAL SURVEYS
}

Steve Masterman, State Geologist \& Director

Publications produced by the Division of Geological \& Geophysical Surveys are available to download from the DGGS website (dggs.alaska.gov). Publications on hard-copy or digital media can be examined or purchased in the Fairbanks office:

\author{
Alaska Division of Geological \& Geophysical Surveys (DGGS) \\ 3354 College Road | Fairbanks, Alaska 99709-3707 \\ Phone: 907.451 .5010 | Fax 907.451.5050 \\ dggspubs@alaska.gov $\mid$ dggs.alaska.gov
}

DGGS publications are also available at:

Alaska State Library, Historical

Collections \& Talking Book Center

395 Whittier Street

Juneau, Alaska 99801

Alaska Resource Library and

Information Services (ARLIS)

3150 C Street, Suite 100

Anchorage, Alaska 99503

\section{Suggested citation:}

Burns, L.E., Graham, G.R.C., Barefoot, J.D., Naibert, T.J., Fugro Airborne Surveys Corps., and Stevens Exploration Management Corp., 2019, Southeastern extension of Salcha RiverPogo electromagnetic and magnetic airborne geophysical survey data compilation: Alaska Division of Geological \& Geophysical Surveys Geophysical Report 2019-9.

http://doi.org/10.14509/30185
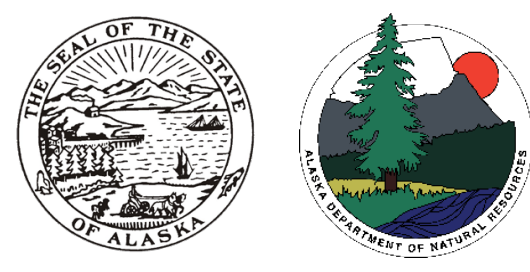


\section{SOUTHEASTERN EXTENSION OF SALCHA RIVER-POGO ELECTROMAGNETIC AND MAGNETIC AIRBORNE GEOPHYSICAL SURVEY DATA COMPILATION}

Burns, L.E. ', Graham, G.R.C. ', Barefoot, J.D. ', Naibert, T.J.' , Fugro Airborne Surveys Corp., and Stevens Exploration Management Corp.

\section{ABSTRACT}

This geophysical survey is located in interior Alaska in the Goodpaster mining district, about 150 kilometers southeast of Fairbanks. Frequency domain electromagnetic and magnetic data were collected with the DIGHEMV system in August 2001. A total of 729.9 line kilometers were collected covering 237.4 square kilometers. Line spacing was 400 meters $(\mathrm{m})$. Data were collected $30 \mathrm{~m}$ above the ground surface from a helicopter towed sensor platform ("bird") on a $30 \mathrm{~m}$ long line.

\section{PURPOSE}

This airborne geophysical survey is part of a program to acquire data on Alaska's most promising mineral belts and districts. The information acquired is aimed at catalyzing new private sector exploration, discovery, and ultimate development and production. The purpose of the survey was to map the magnetic and conductive properties of the survey area. Mineral prospects in the survey area are related to Pogo mine. Other gold and base-metal anomalies, altered zones, favorable lithologies, and structural zones are known to exist throughout the survey area.

\section{SURVEY OVERVIEW DESCRIPTION}

This document provides an overview of the survey and includes text and figures of select primary and derivative products of this survey. A table of digital data packages available for download is provided to assist users in data selection. For reference, a catalog of the available maps is presented in reduced resolution. Please consult the metadata, project report, and digital data packages for more information and data.

\section{ACKNOWLEDGMENTS}

Funding was provided by the Alaska State Legislature as part of the DGGS Airborne Geophysical/Geological Mineral Inventory (AGGMI) program.

\footnotetext{
${ }^{1}$ Alaska Division of Geological \& Geophysical Surveys, 3354 College Road, Fairbanks, Alaska 99709-3707
} 


\begin{tabular}{|c|c|c|}
\hline Data Type & Provider & Description \\
\hline ascii_data & contractor & ASCII format line data, other ASCII data \\
\hline databases_geosoft & contractor & $\begin{array}{l}\text { Geosoft format database of final line data, other } \\
\text { Geosoft format databases }\end{array}$ \\
\hline documents & contractor and DGGS & $\begin{array}{l}\text { Project and field reports, survey background } \\
\text { information, gridded data explanations, other } \\
\text { documentation }\end{array}$ \\
\hline grids_ermapper & contractor & $\begin{array}{l}\text { Geographically registered gridded data, ER Mapper } \\
\text { ERS format }\end{array}$ \\
\hline grids_geosoft & contractor and DGGS & $\begin{array}{l}\text { Geosoft-format grids, these grids can be viewed in } \\
\text { ESRI ArcMap using a free plugin from Geosoft or the } \\
\text { free viewer available from Geosoft }\end{array}$ \\
\hline images_registered & DGGS & GeoTiff format images of all gridded data \\
\hline $\mathrm{kmz}$ & DGGS & $\begin{array}{l}\text { keyhole markup language }(\mathrm{kml}) \mathrm{kmz} \text { archive files of } \\
\text { project data. Viewable in Google Earth and other } \\
\text { compatible programs }\end{array}$ \\
\hline maps_pdf_format & contractor & Printable maps in pdf format \\
\hline maps_prn_format & contractor & $\begin{array}{l}\text { Printable maps in HPGL/2 printer file format with } \\
\text { extension .prn }\end{array}$ \\
\hline profiles_stacked & contractor & $\begin{array}{l}\text { Distance-based profiles of the digitally recorded } \\
\text { geophysical data are generated and plotted at an } \\
\text { appropriate scale. The profiles display } \\
\text { electromagnetic anomalies with their respective } \\
\text { interpretive symbols. Printable in pdf format }\end{array}$ \\
\hline vector_data & contractor and DGGS & $\begin{array}{l}\text { Line path, data contours, and survey boundary in } \\
\text { ESRI shapefile (SHP) format, ESRI Geodatabase } \\
\text { format, and/or AutoCAD dxf format }\end{array}$ \\
\hline video_flightpath & contractor & Survey flight path downward facing video \\
\hline
\end{tabular}




\section{REFERENCES}

Akima, H., 1970, A new method of interpolation and smooth curve fitting based on local procedures: Journal of the Association of Computing Machinery, v. 17, n. 4, p. 589-602.

Alaska Division of Geological \& Geophysical Surveys, Fugro Airborne Surveys, Stevens Exploration Management Corp., and Burns, L.E., 2002, Plot files of the airborne geophysical survey data of the southeastern extension of Salcha River-Pogo survey, Goodpaster mining district, east-central Alaska: Alaska Division of Geological \& Geophysical Surveys Geophysical Report 2002-1, 1 DVD. http://doi.org/10.14509/2775

Alaska Division of Geological \& Geophysical Surveys, Fugro Airborne Surveys, Stevens Exploration Management Corp., and Burns, L.E., 2002, Line, gridded, and vector data of airborne geophysical survey data for the southeastern extension of Salcha River-Pogo survey, Goodpaster mining district, east-central Alaska: Alaska Division of Geological \& Geophysical Surveys Geophysical Report 2002-2, 1 DVD. http://doi.org/10.14509/2789

Alaska Division of Geological \& Geophysical Surveys, Fugro Airborne Surveys, Stevens Exploration Management Corp., and Burns, L.E., 2002, Gridded and vector data of airborne geophysical survey data for the southeastern extension of Salcha River-Pogo survey, Goodpaster mining district, eastcentral Alaska: Alaska Division of Geological \& Geophysical Surveys Geophysical Report 2002-3. http://doi.org/10.14509/2790

Burns, L.E., 1997, Portfolio of aeromagnetic and resistivity maps of the extended coverage of the RampartManley mining district: Alaska Division of Geological \& Geophysical Surveys Public Data File 97-23, 13 p. http://doi.org/10.14509/1766

Burns, L.E., 2002, Portfolio of aeromagnetic and resistivity maps of the southeastern extension of the Salcha River-Pogo survey, Goodpaster mining district, east-central Alaska: Alaska Division of Geological \& Geophysical Surveys Geophysical Report 2002-5, 17 p. http://doi.org/10.14509/2792

Fraser, D.C., 1978, Resistivity mapping with an airborne multicoil electromagnetic system: Geophysics, v. 43, p. 144-172.

Pritchard, R.A., and Fugro Airborne Surveys, 2002, Project report of the airborne geophysical survey of the southeastern extension of the Salcha River-Pogo survey, Goodpaster mining district, east-central Alaska: Alaska Division of Geological \& Geophysical Surveys Geophysical Report 2002-4, 80 p., 1 sheet, scale 1:63,360. http://doi.org/10.14509/2791 


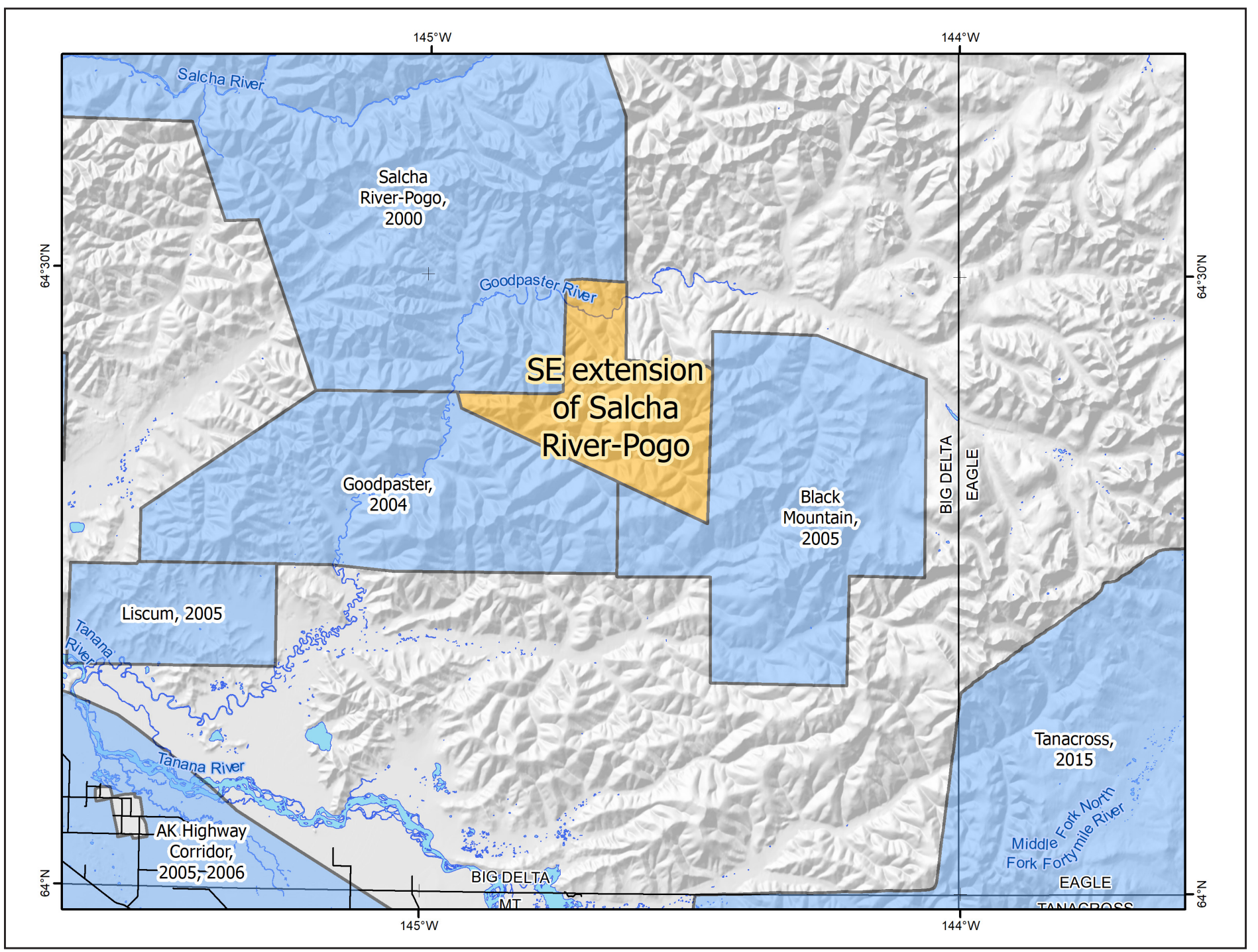

Figure 1. Southeastern extension of Salcha River-Pogo electromagnetic and magnetic airborne geophysical survey location shown in Alaska (right). Southeastern extension of Salcha River - Pogo survey area shown with adjacent DGGS geophysical surveys, landmarks, relevant 1:250,000-scale quadrangle boundaries, mountain ranges, rivers, glaciers, and elevation hillshade. 


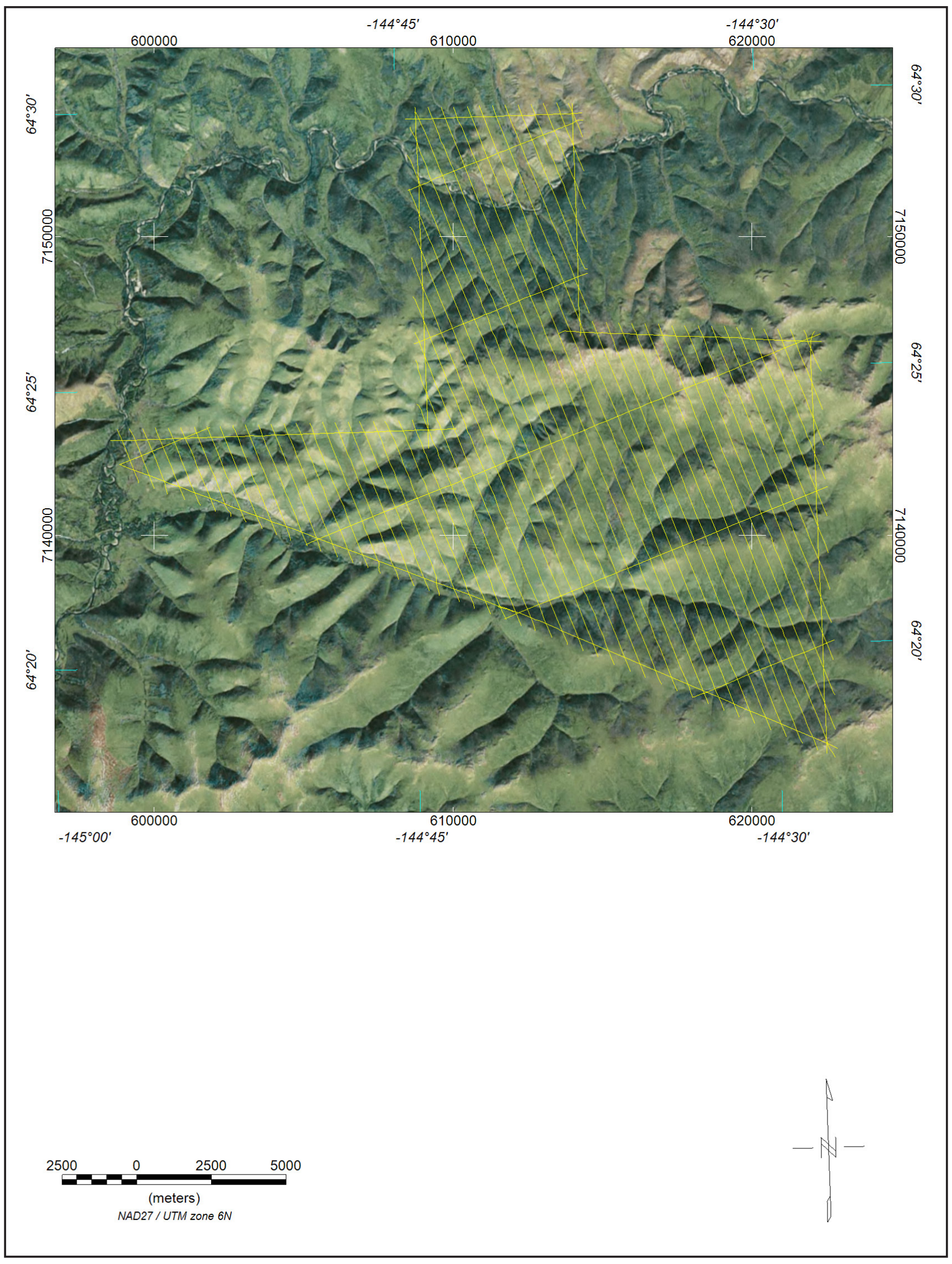

Figure 2. Flight path with orthometric image. 


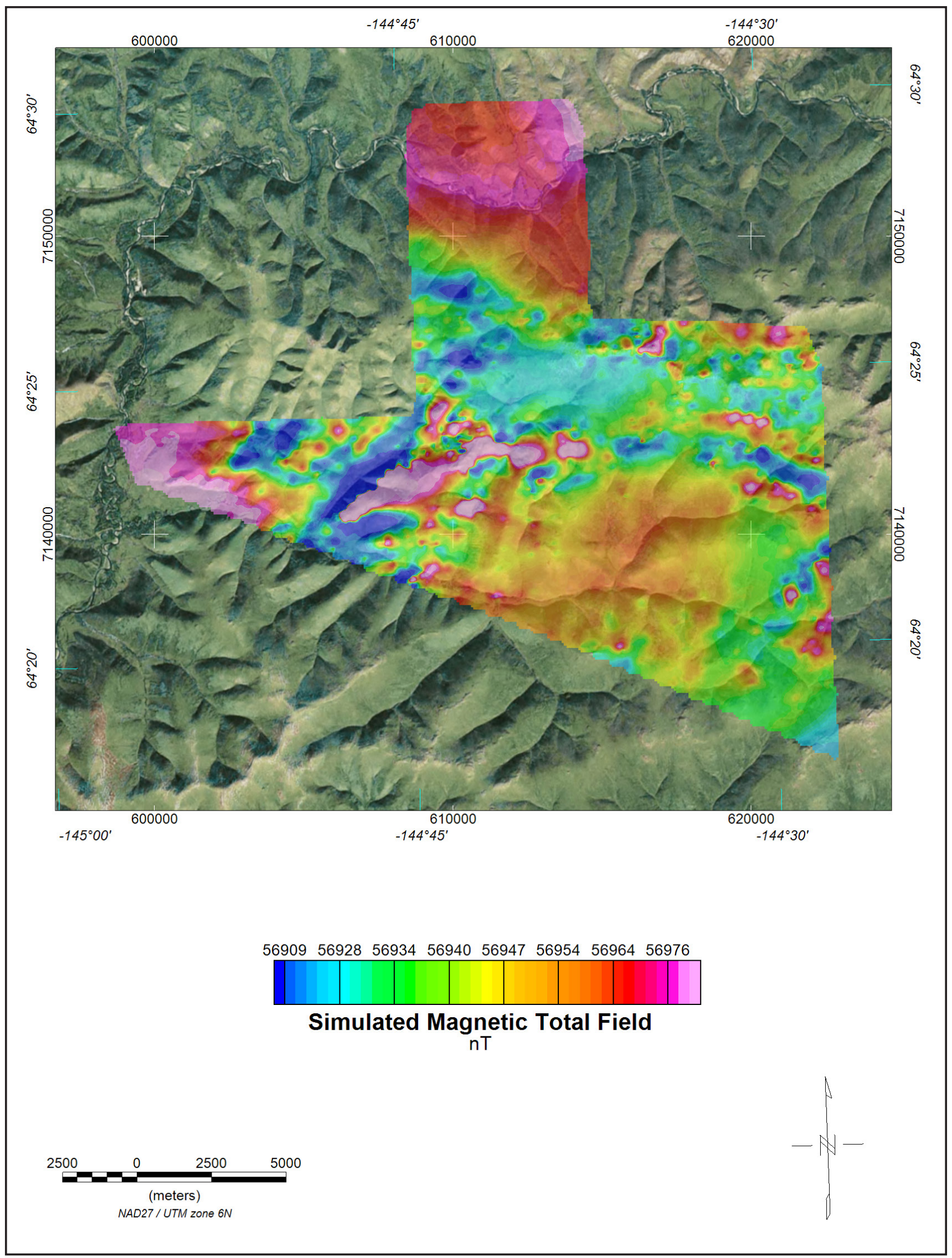

Figure 3. The simulated magnetic total field data were created using digitally recorded data from a Scintrex cesium magnetometer. Data were collected at a sampling interval of 0.1 seconds. The magnetic data were (1) corrected for diurnal variations by subtracting the digitally recorded base station magnetic data, (2) IGRF corrected (IGRF model 2000, updated August 2001, updated for date of flight and altimeter variations), (3) leveled to the tie line data, (4) a constant value of approximately 56,000 nT was added to all data, and (5) interpolated onto a regular $100 \mathrm{~m}$ grid using a modified Akima (1970) technique. 


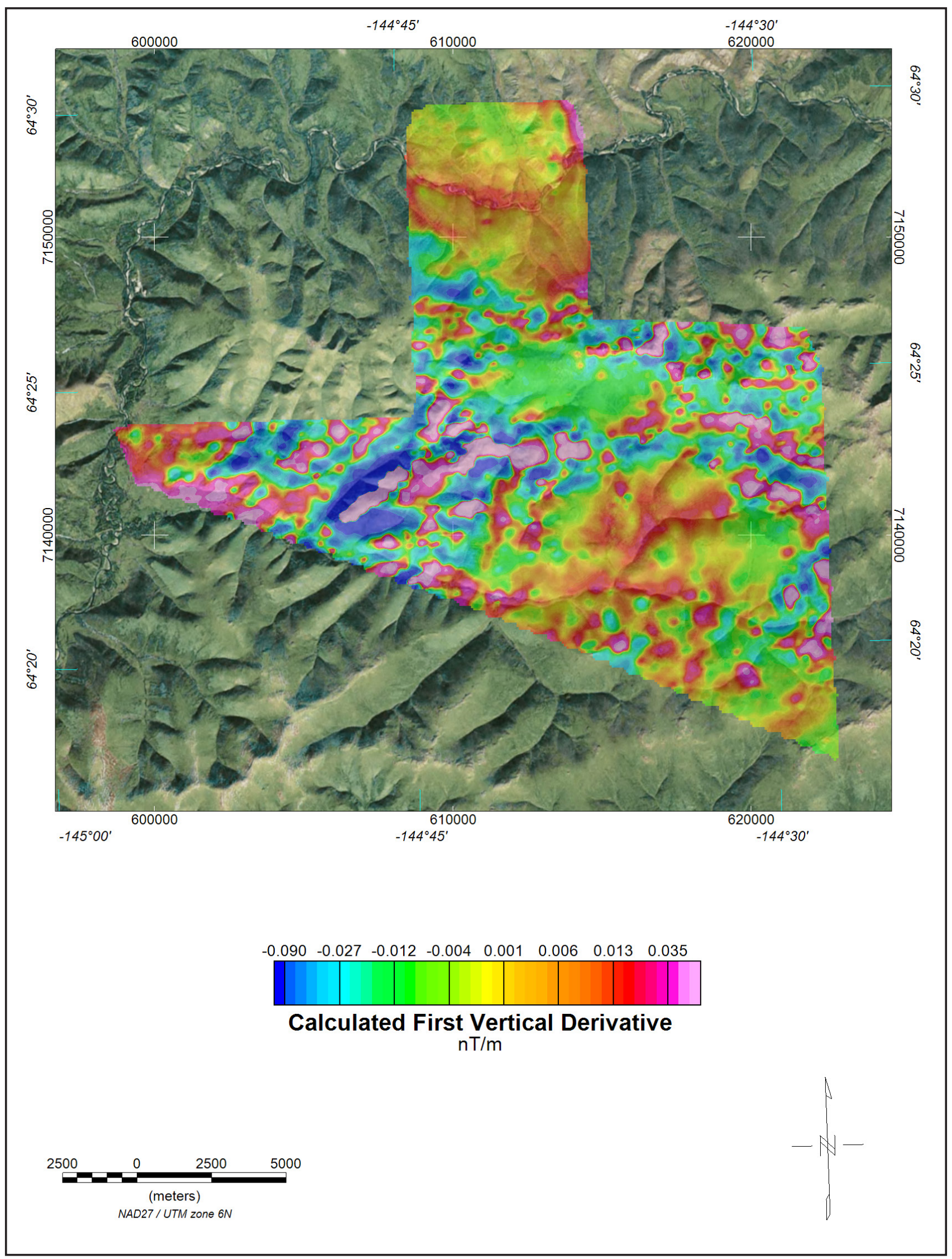

Figure 4. The first vertical derivative grid was calculated from the diurnally-corrected, IGRF-corrected total magnetic field grid using a FFT base frequency domain filtering algorithm. The resulting first vertical derivative grid provides better definition and resolution of near- surface magnetic units and helps to identify weak magnetic features that may not be evident on the total field data. 


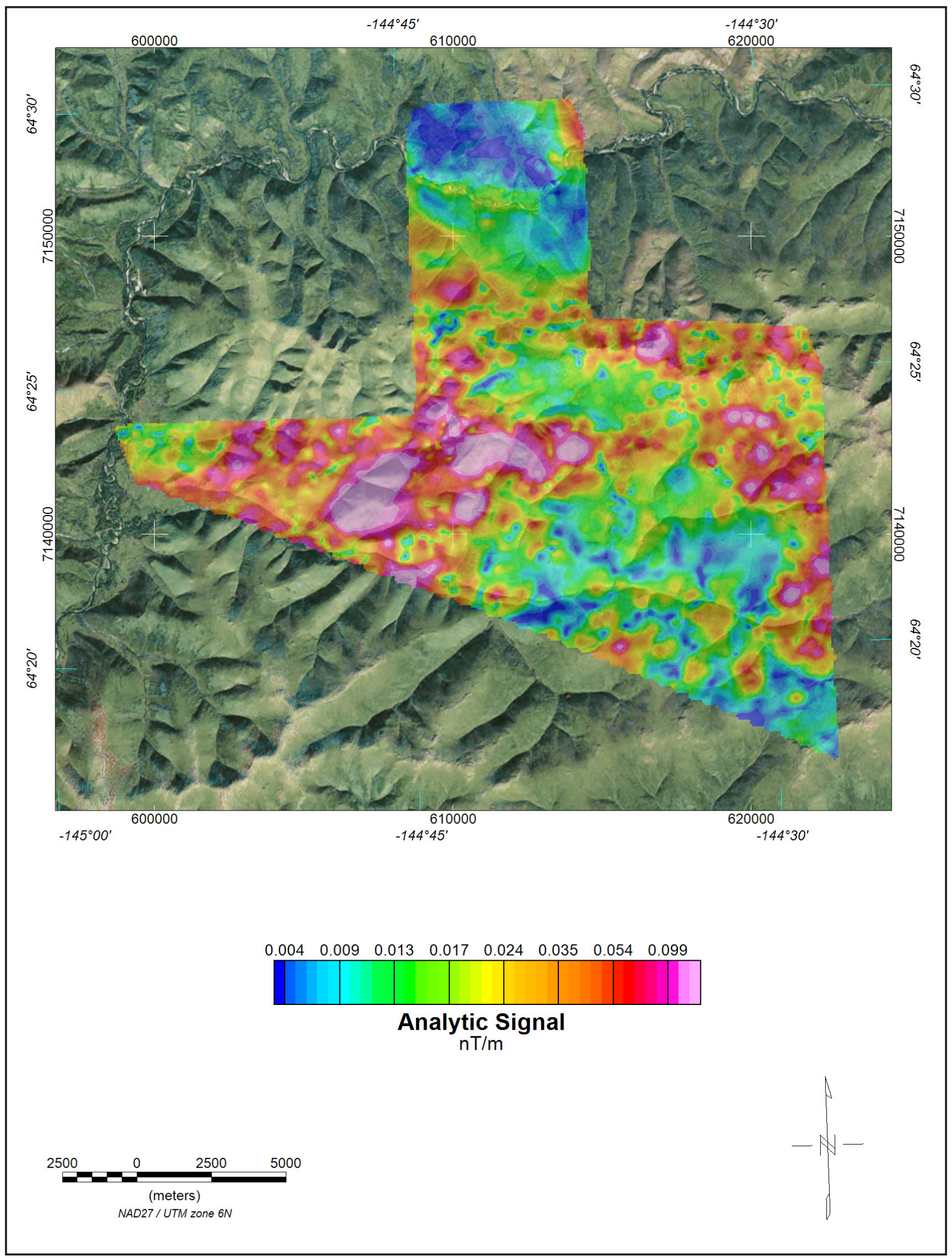

Figure 5. Analytic signal is the total amplitude of all directions of magnetic gradient calculated from the sum of the squares of the three orthogonal gradients. Mapped highs in the calculated analytic signal of magnetic parameter locate the anomalous source body edges and corners (such as contacts, fault/shear zones, etc.). Analytic signal maxima are located directly over faults and contacts, regardless of structural dip, and independent of the direction of the induced and/or remanent magnetizations. 


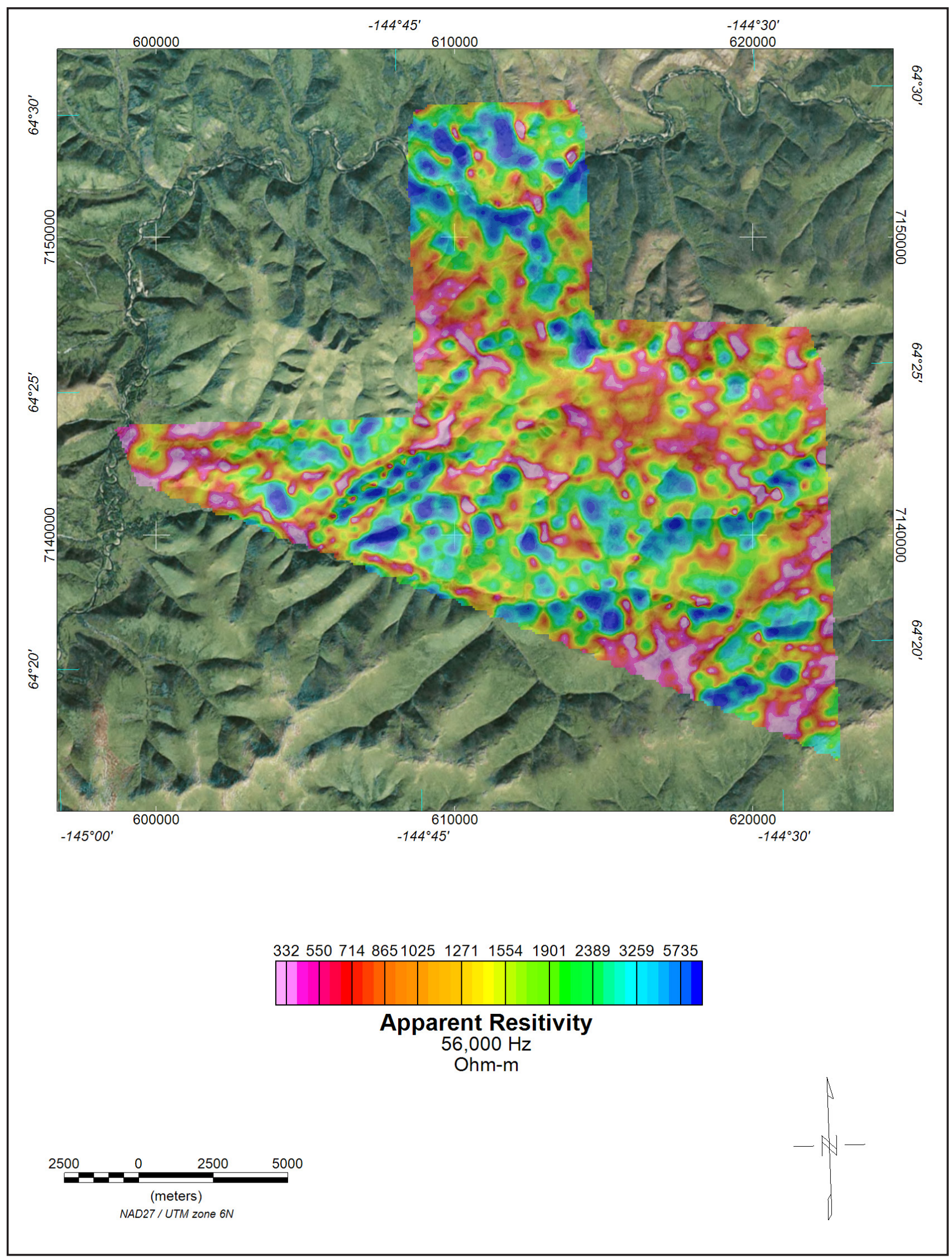

Figure 6. The DIGHEM ${ }^{\vee}$ EM system measured inphase and quadrature components at five frequencies. Two vertical coaxial coil-pairs operated at 1000 and $5500 \mathrm{~Hz}$ while three horizontal coplanar coil-pairs operated at 900, 7,200, and 56,000 Hz. EM data were sampled at 0.1 second intervals. The EM system responds to bedrock conductors, conductive overburden, and cultural sources. Apparent resistivity is generated from the inphase and quadrature component of the coplanar $56,000 \mathrm{~Hz}$ using the pseudo-layer half space model (Fraser 1978). The data were interpolated onto a regular $100 \mathrm{~m}$ grid using a modified Akima (1970) technique. 


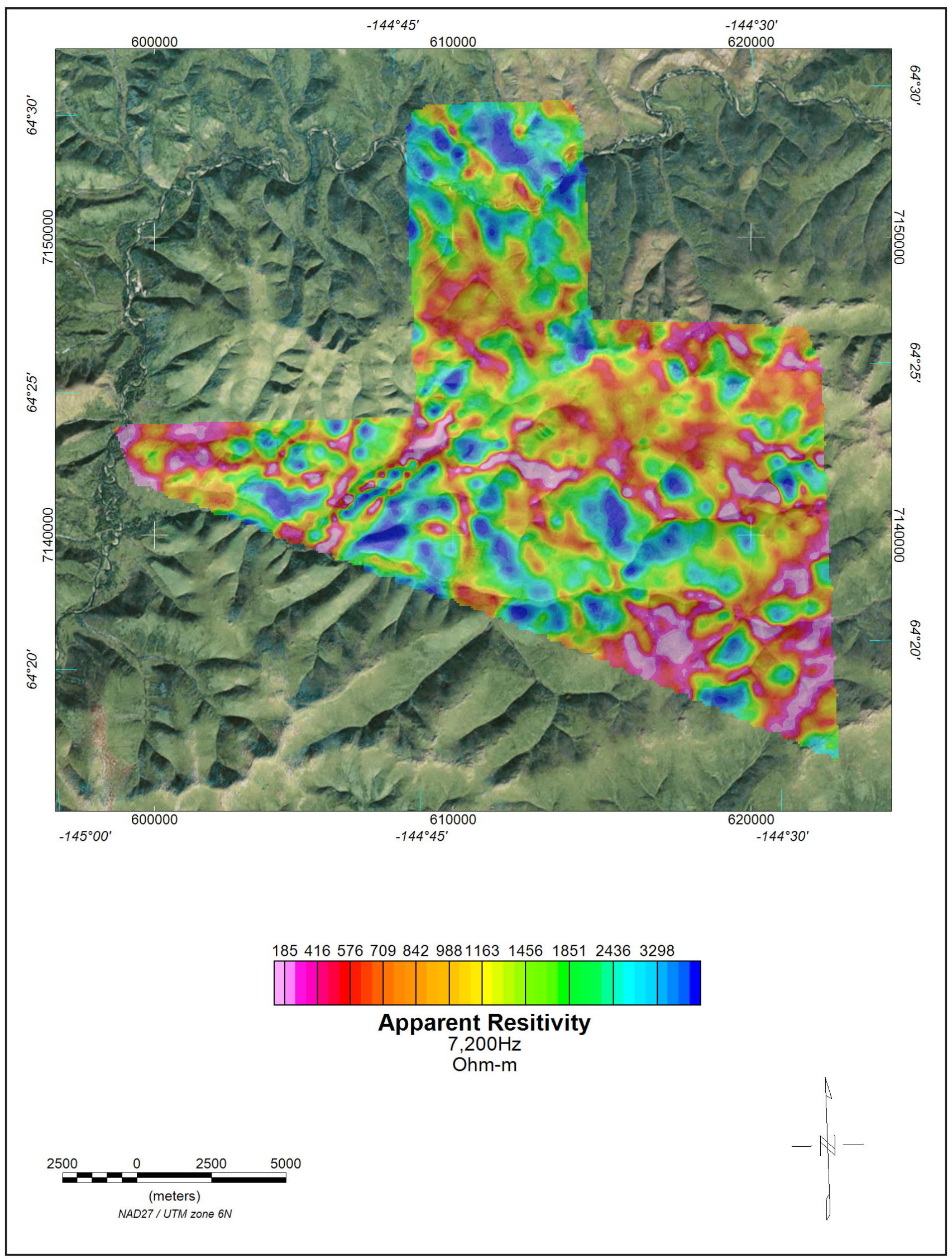

Figure 7. The DIGHEM ${ }^{\vee}$ EM system measured inphase and quadrature components at five frequencies. Two vertical coaxial coil-pairs operated at 1000 and $5500 \mathrm{~Hz}$ while three horizontal coplanar coil-pairs operated at 900, 7,200, and 56,000 Hz. EM data were sampled at 0.1 second intervals. The EM system responds to bedrock conductors, conductive overburden, and cultural sources. Apparent resistivity is generated from the inphase and quadrature component of the coplanar $7,200 \mathrm{~Hz}$ using the pseudo-layer half space model (Fraser 1978). The data were interpolated onto a regular $100 \mathrm{~m}$ grid using a modified Akima (1970) technique. 


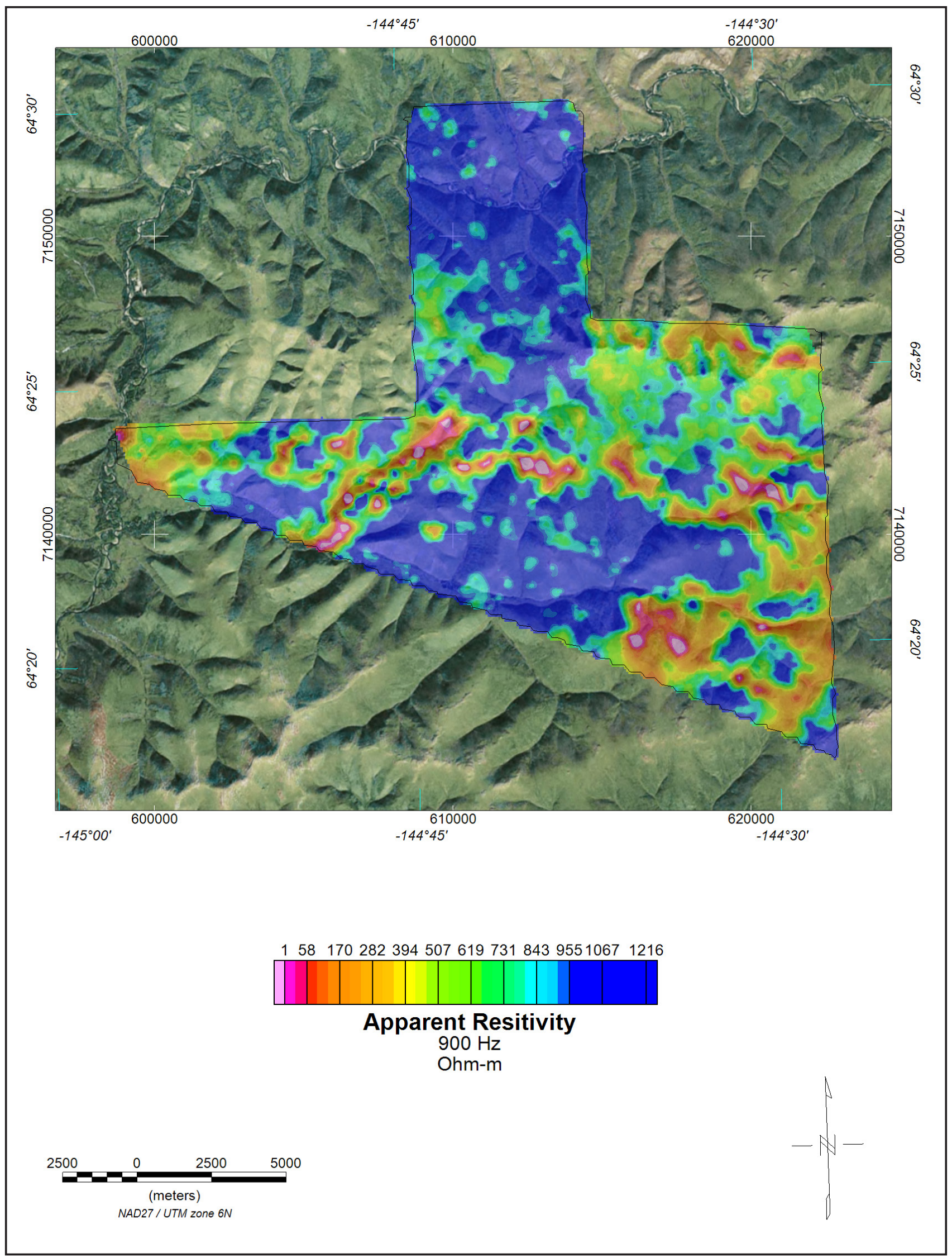

Figure 8. The DIGHEM ${ }^{\vee}$ EM system measured inphase and quadrature components at five frequencies. Two vertical coaxial coil-pairs operated at 1000 and $5500 \mathrm{~Hz}$ while three horizontal coplanar coil-pairs operated at 900, 7,200, and 56,000 Hz. EM data were sampled at 0.1 second intervals. The EM system responds to bedrock conductors, conductive overburden, and cultural sources. Apparent resistivity is generated from the inphase and quadrature component of the coplanar $900 \mathrm{~Hz}$ using the pseudo-layer half space model (Fraser 1978). The data were interpolated onto a regular $100 \mathrm{~m}$ grid using a modified Akima (1970) technique. 
Table 1. Copies of the following maps are included at the end of this booklet. The low-resolution, page-size maps included in this booklet are intended to be used as a search tool and are not the final product. Large-scale, full-resolution versions of each map are available to download on this publication's citation page: http://doi.org/10.14509/30185.

\begin{tabular}{|c|c|}
\hline Map Title & Description \\
\hline salchapogo_ext_flightlines_topo_map.pdf & Flight lines with topographic base map \\
\hline salchapogo_ext_sim_magtf_topo_map.pdf & Simulated total magnetic field grid with topographic base map \\
\hline salchapogo_ext_sim_magtf_contours_plss_map.pdf & Simulated total magnetic field grid with contours and public land survey system base layer \\
\hline salchapogo_ext_sim_magtf_shaded_plss_map.pdf & Color shaded simulated total magnetic field grid with public land survey system base layer \\
\hline salchapogo_ext_res7200hz_topo_map.pdf & 7,200 Hz coplanar apparent resistivity grid with topographic base map \\
\hline salchapogo_ext_res7200hz_contours_plss_map.pdf & 7,200 Hz coplanar apparent resistivity grid with contours and public land survey system base layer \\
\hline salchapogo_ext_res7200hz_bw_contours_plss_map.pdf & Black and white $7,200 \mathrm{~Hz}$ coplanar apparent resistitity contours with public land survey system base layer \\
\hline salchapogo_ext_res900hz_topo_map.pdf & $900 \mathrm{~Hz}$ coplanar apparent resistivity grid with topographic base map \\
\hline salchapogo_ext_res900hz_contours_plss_map.pdf & $900 \mathrm{~Hz}$ coplanar apparent resistivity grid with contours and public land survey system base layer \\
\hline salchapogo_ext_res900hz_bw_contours_plss_map.pdf & Black and white $900 \mathrm{~Hz}$ coplanar apparent resistivity contours with public land survey system base layer \\
\hline salchapogo_ext_emanomalies_sim_magtf_contours_plss_map.pdf & EM anomalies and simulated total magnetic field contours with flight lines and public land survey system base layer \\
\hline $\begin{array}{l}\text { salchapogo_ext_emanomalies_sim_magtf_contours_detailed_topo_ } \\
\text { map_1of2.pdf }\end{array}$ & Detailed EM anomalies and simulated total magnetic field contours with flight lines and topographic base map \\
\hline $\begin{array}{l}\text { salchapogo_ext_emanomalies_sim_magtf_contours_detailed_topo_ } \\
\text { map_2of2.pdf }\end{array}$ & Detailed EM anomalies and simulated total magnetic field contours with flight lines and topographic base map \\
\hline
\end{tabular}




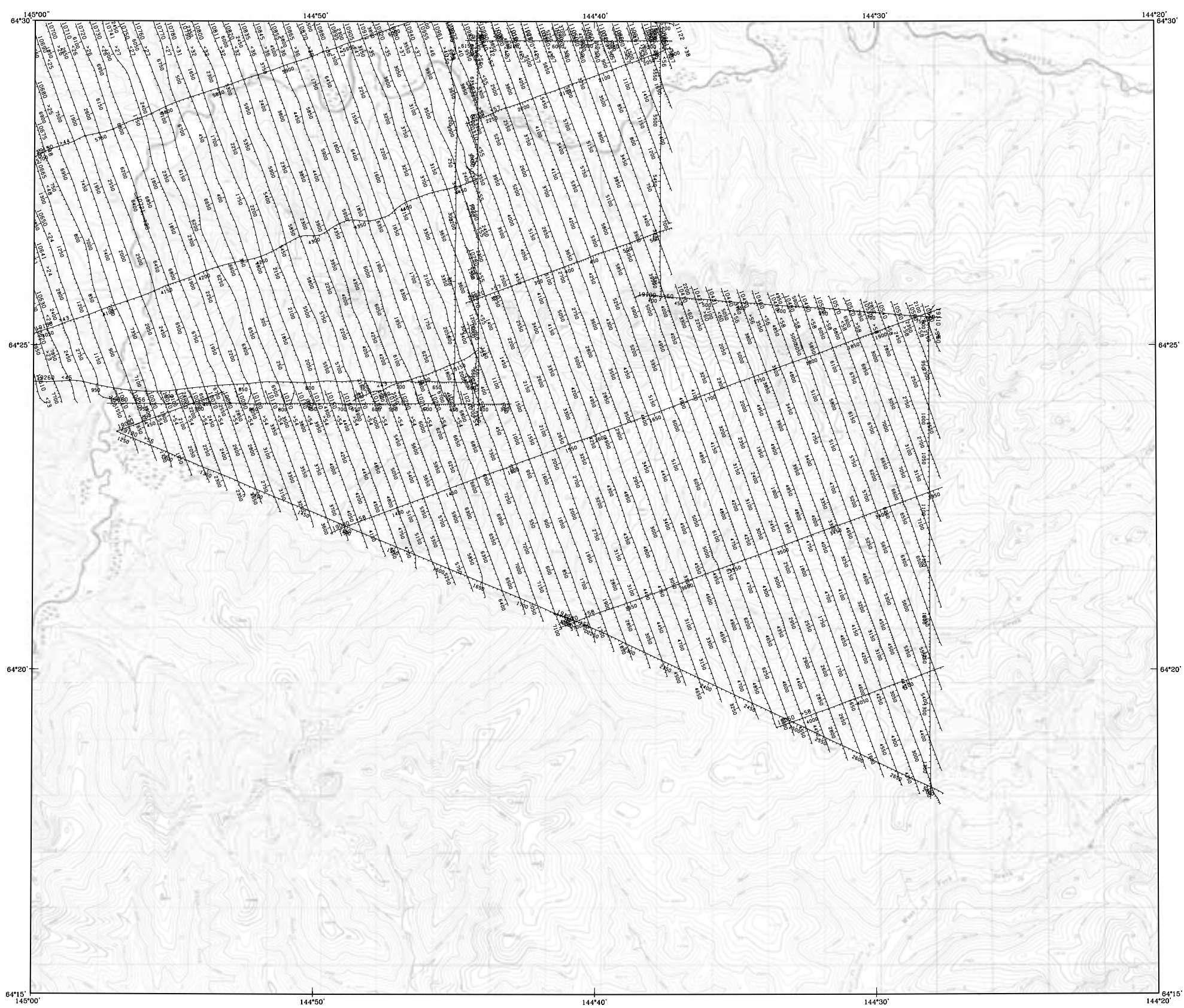

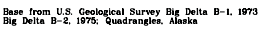

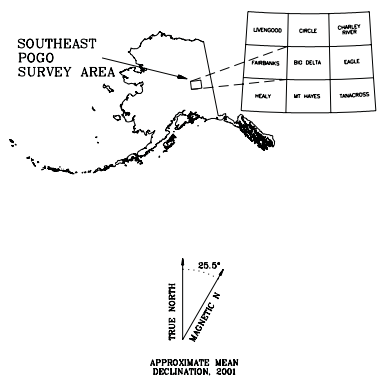

DESCRIPTIVE NOTES

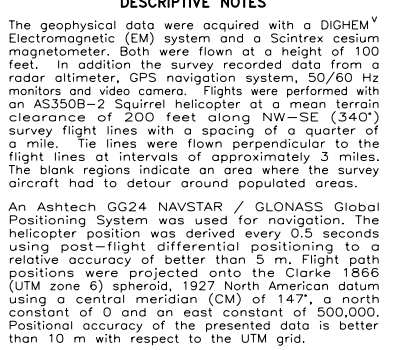

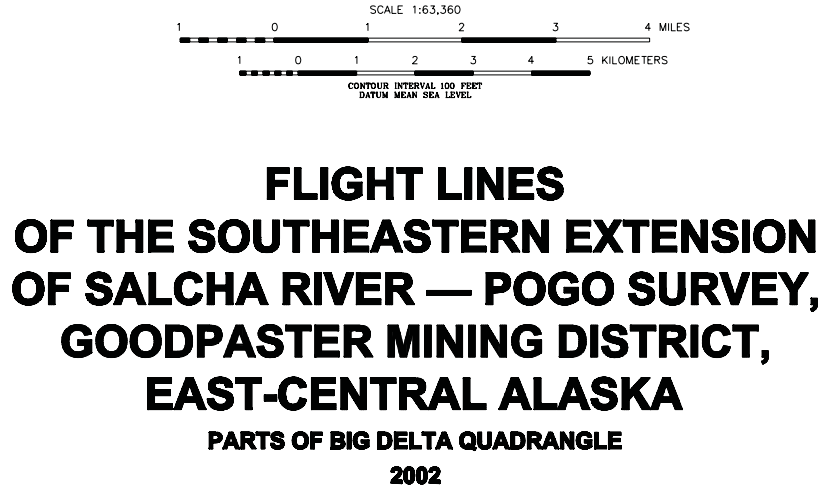

2002

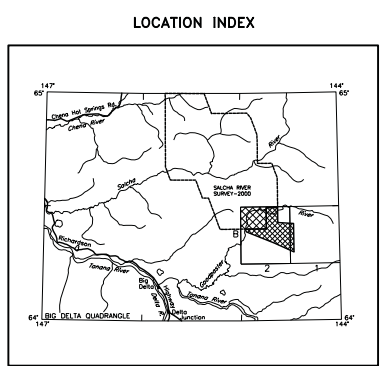

SURVEY HISTORY

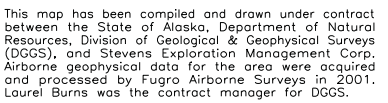

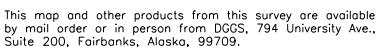

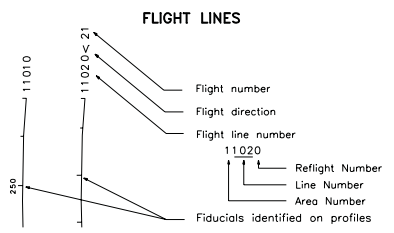




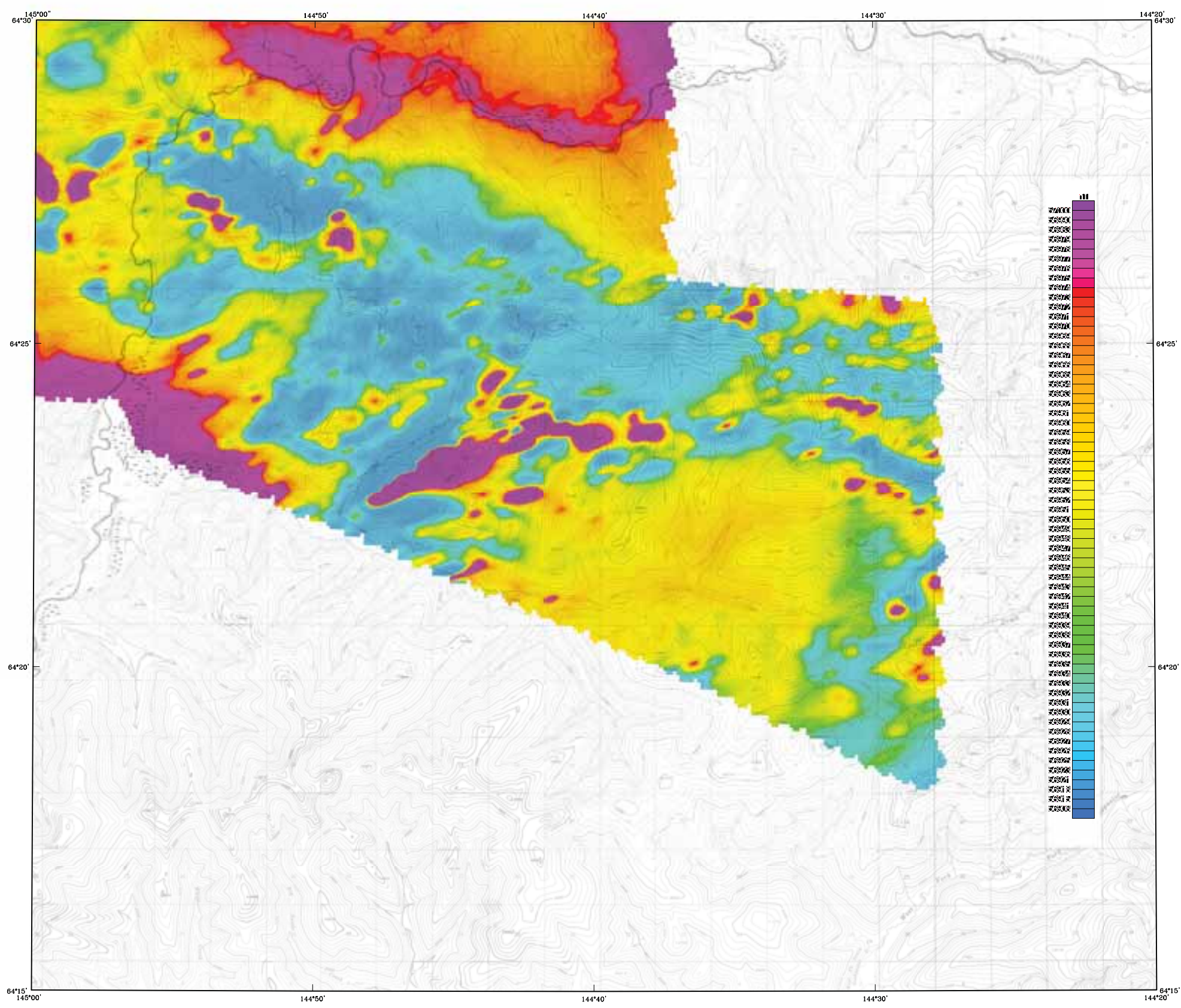

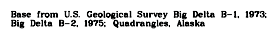
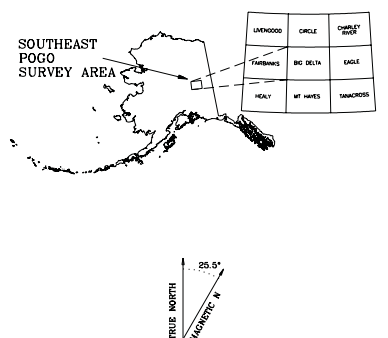

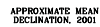

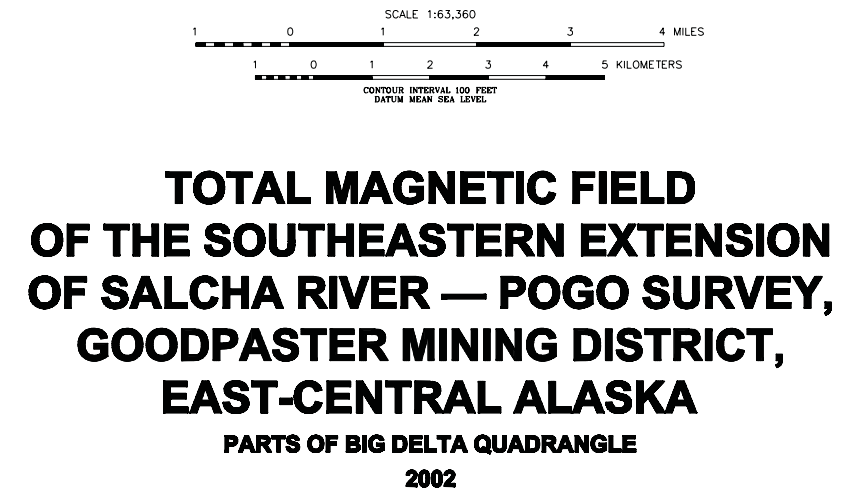

TOTAL MAGNETIC FIELD OF THE SOUTHEASTERN EXTENSION OF SALCHA RIVER - POGO SURVEY, EAST-CENTRAL ALASKA 2002

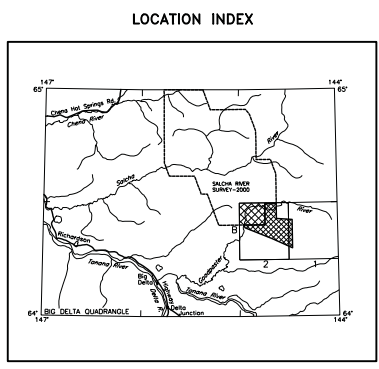

SURVEY HISTORY

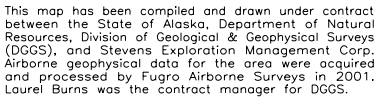

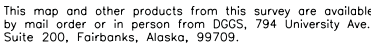

TOTAL MAGNETIC FIELD

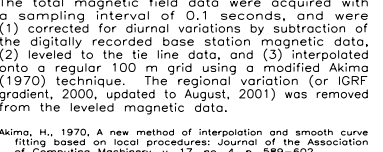




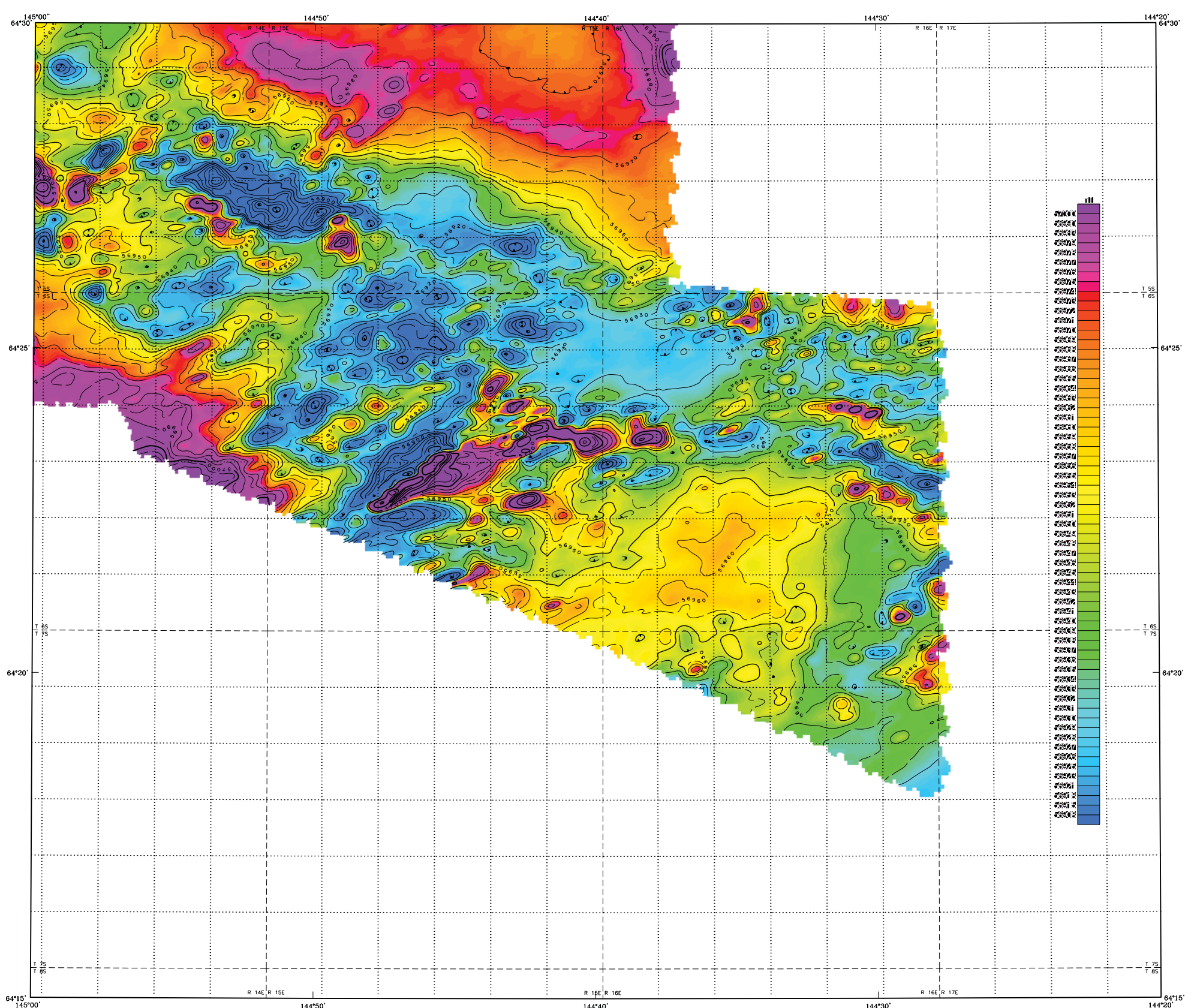

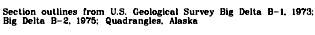

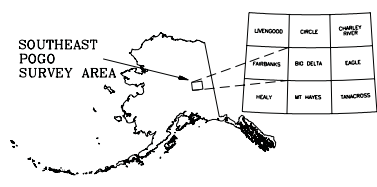

DESCRIPTIVE NOTES

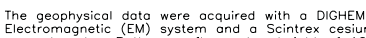

mognetometer. Both were flown ot a heintrex cesium

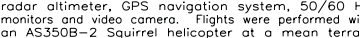

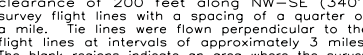

thight lines ot intervals of aproximately 3 miles
The blank regions indicate an oreo where the survey
oircraft hod to detour oround populated ores.

An Ashtech GG24 NAVSTAR / GLONASS Global
Positioning System wos used for novigotion. The

helicopter position was derived every

relotive occuracy of better than $5 \mathrm{~m}$. Flight poth
positions were projected onto the Clarke 1866
(UTM zone 6 ) spheroid, 1927 North American datum
(UTM

using a central meridion (CM) of $147^{\circ}$ \% norm
constant of 0 and on east constant of 500,000

TOTAL MAGNETIC FIELD

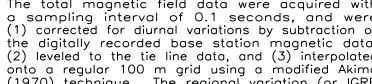

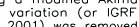

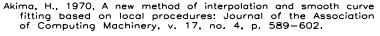

SCALE $1: 63,360$

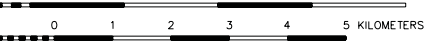

TOTAL MAGNETIC FIELD OF THE SOUTHEASTERN EXTENSION OF SALCHA RIVER — POGO SURVEY, GOODPASTER MINING DISTRICT, EAST-CENTRAL ALASKA

PARTS OF BIG DELTA QUADRANGLE

2002

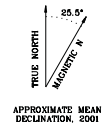

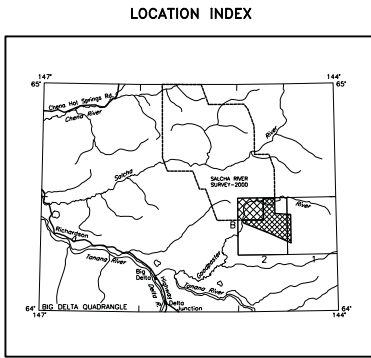

SURVEY HISTORY

This map has been compiled and drawn under contrac
between the State of Alaska, Department of Natural
Resureses, Division of Geological \& Geophysical Survey Resources, Division of Geological \& Geophysical Surveys
(DGGS), and Stevens Exploration Management Corp. Airt processed by Fugro Airborne Surveys in 200
and
Lourel Burns was the contract manager for DGGS. This map ond other products from this survey are available
by mai order or in person from DGSGS, 794 University Ave.
Suite 200, Foirbonks, Alaska, 99709 .

MAGNETIC CONTOUR INTERVAL

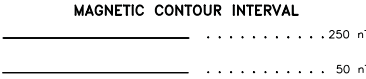




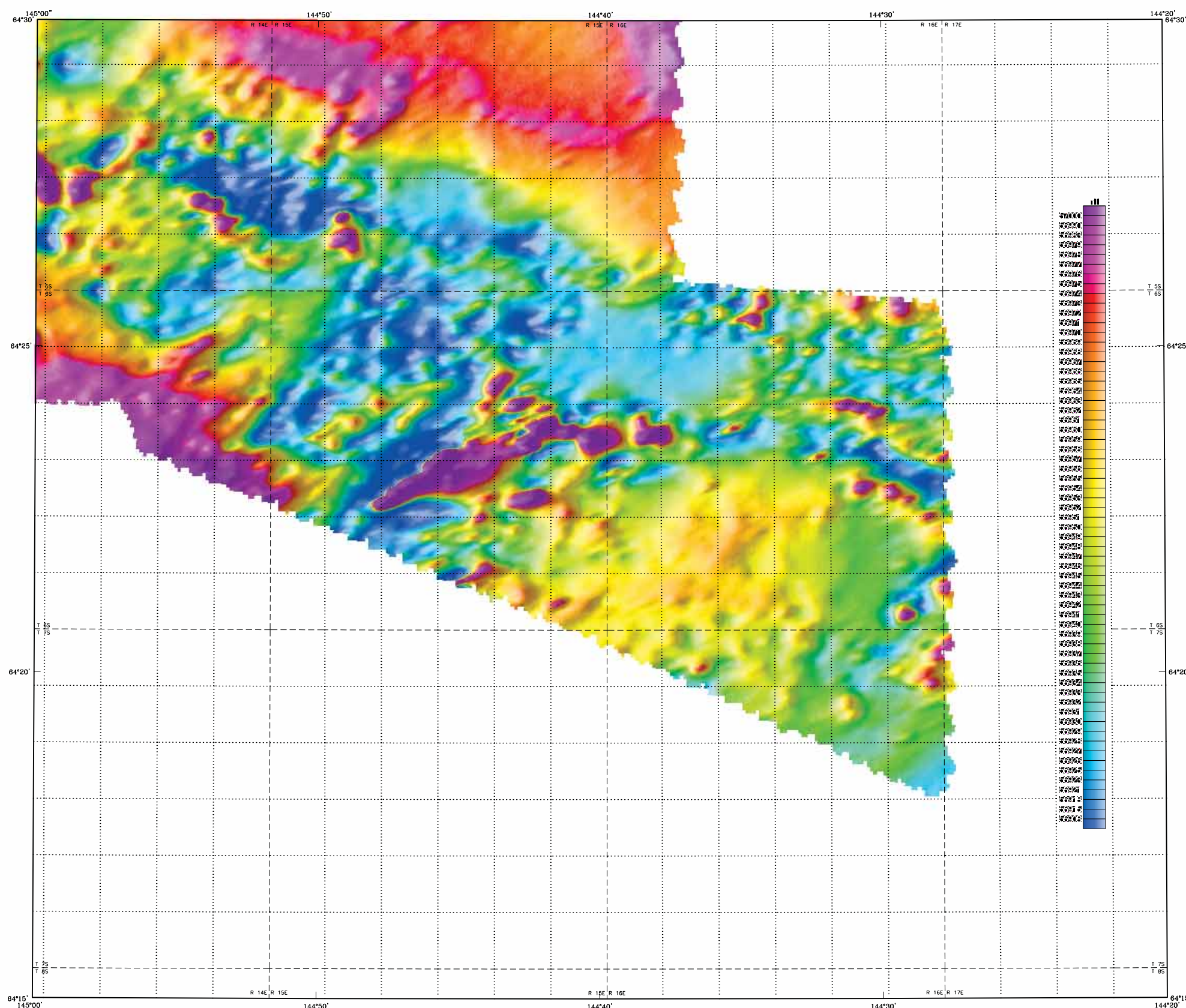

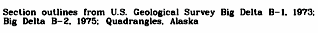

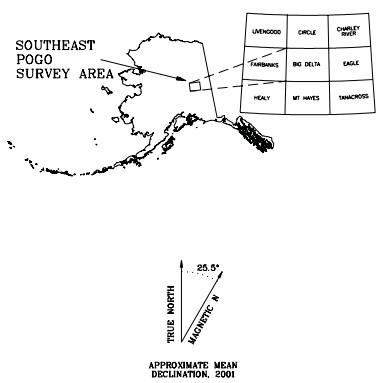

DESCRIPTIVE NOTES

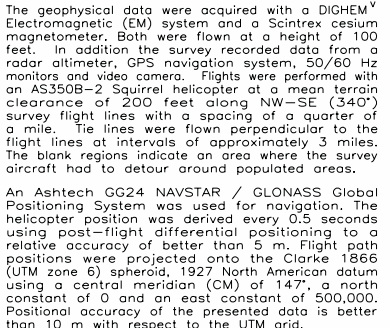

COLOR SHADOW TOTAL MAGNETIC FIELD OF THE SOUTHEASTERN EXTENSION OF SALCHA RIVER - POGO SURVEY, GOODPASTER MINING DISTRICT, EAST-CENTRAL ALASKA PARTS OF BIG DELTA QUADRANGLE 2002

Sun Azimuth: 270 degrees Sun Inclination: 35 degrees

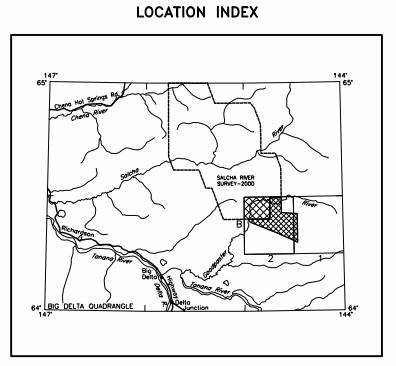

SURVEY HISTORY

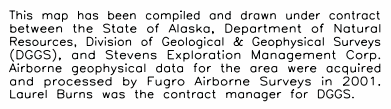

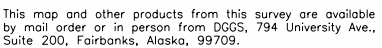




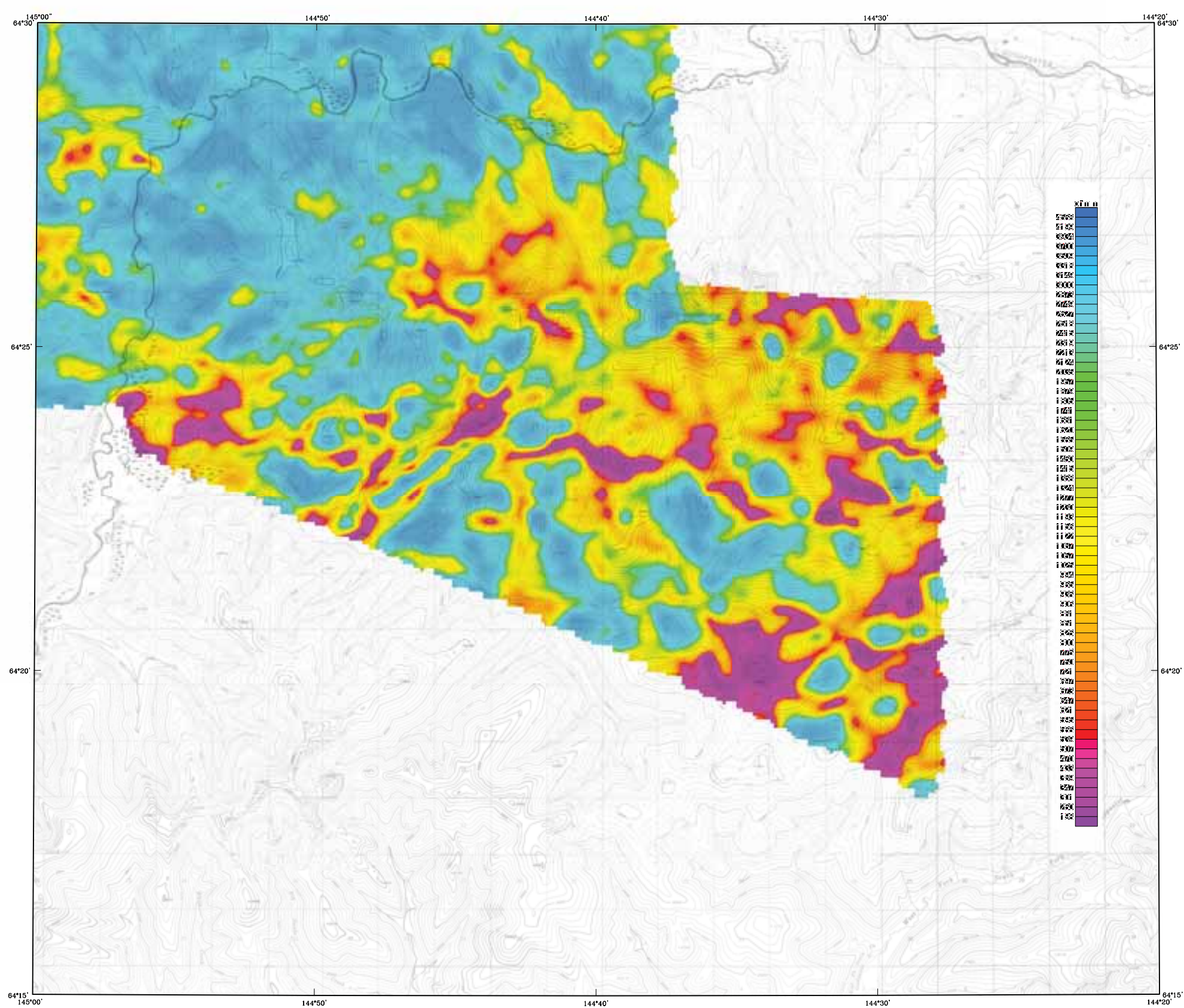

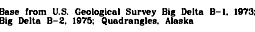

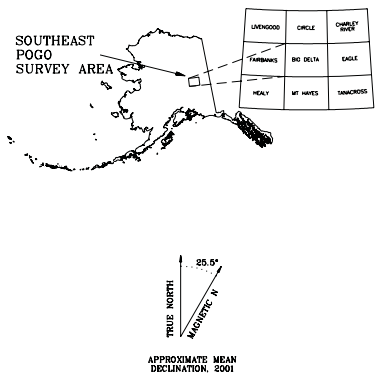

DESCRIPTIVE NOTES

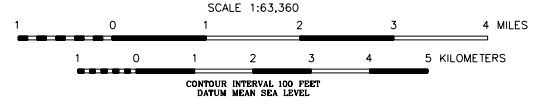

$7200 \mathrm{~Hz}$ COPLANAR RESISTIVITY OF THE SOUTHEASTERN EXTENSION OF SALCHA RIVER — POGO SURVEY, GOODPASTER MINING DISTRICT, EAST-CENTRAL ALASKA

PARTS OF BIG DELTA QUADRANGLE

2002

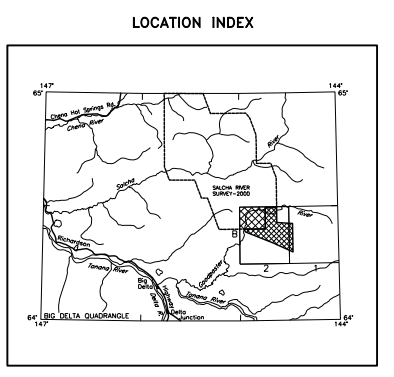

SURVEY HISTORY

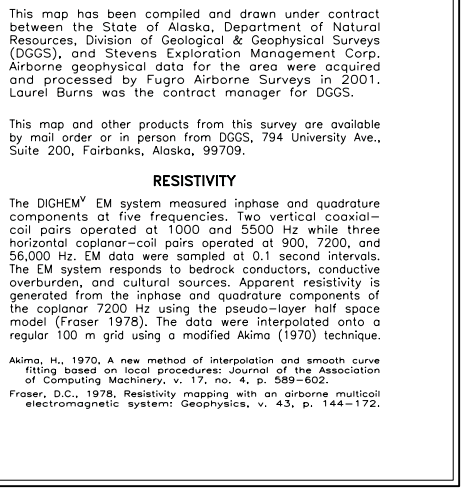




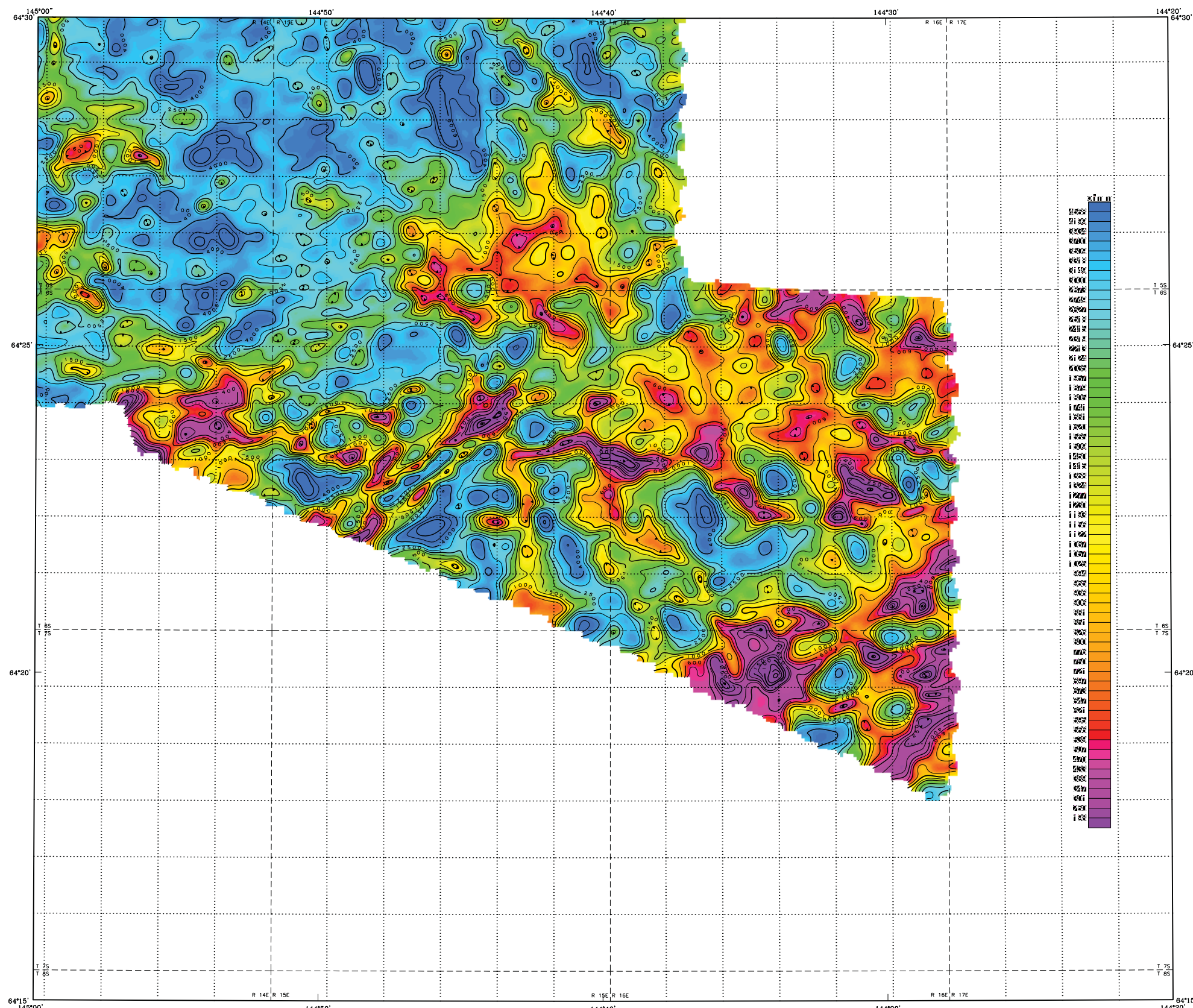

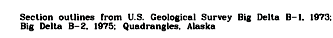

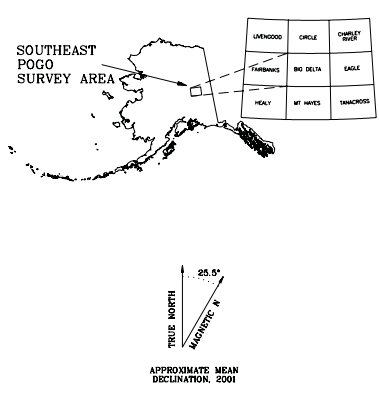

DESCRIPTIVE NOTES

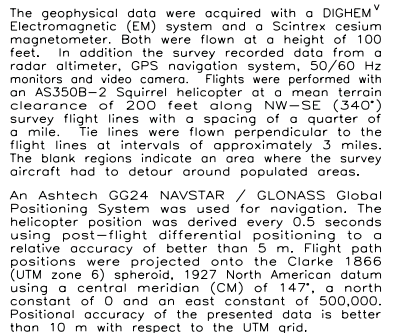

SCALE $1: 63,360$
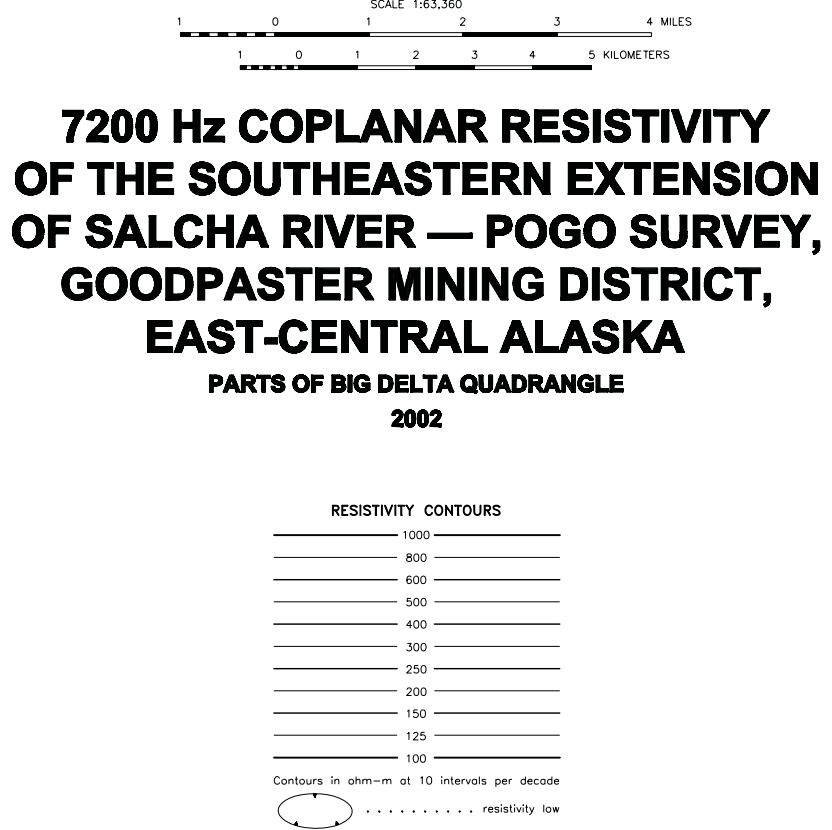

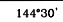

$144^{\circ} 20^{\circ}$

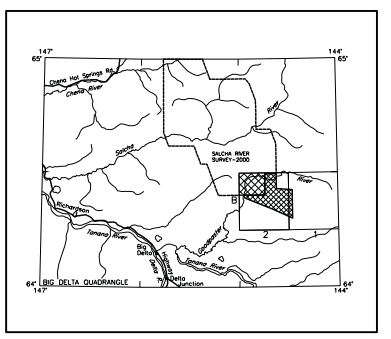

SURVEY HISTORY

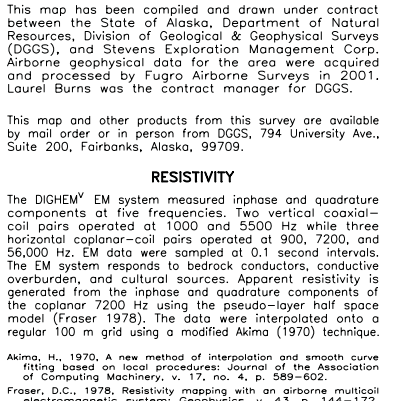




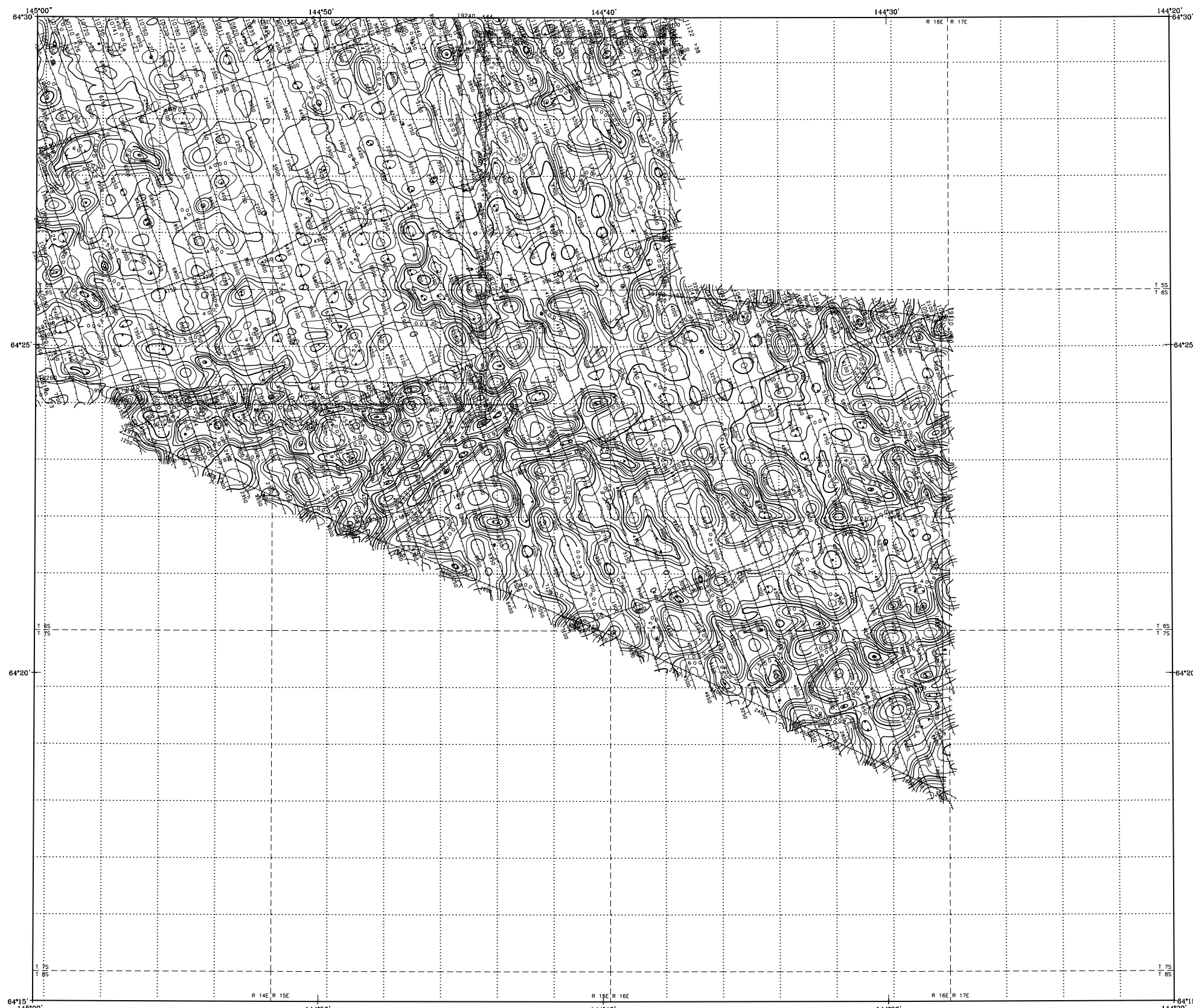

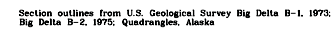
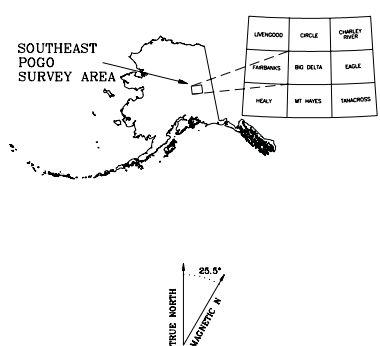

APPROXXATR MEAN
DECLNATATON, 2001
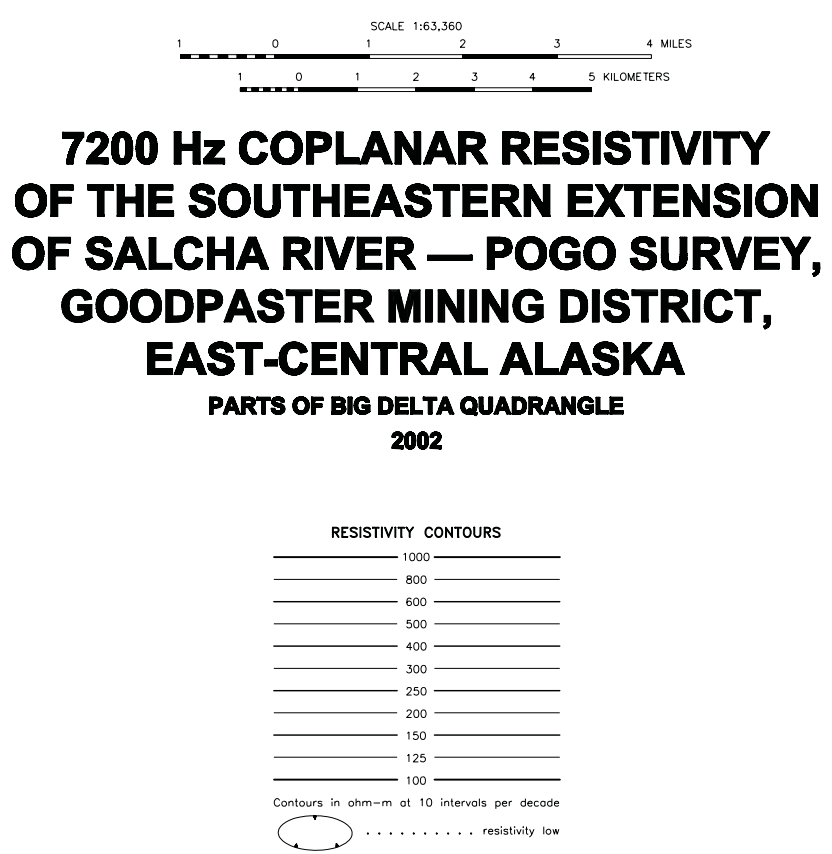

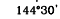

${ }_{144^{\circ} 20^{\circ}}$

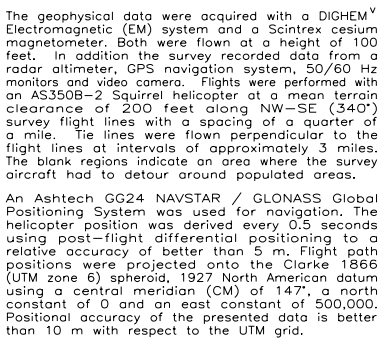

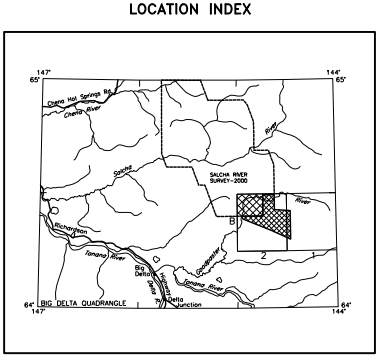

SURVEY HISTORY

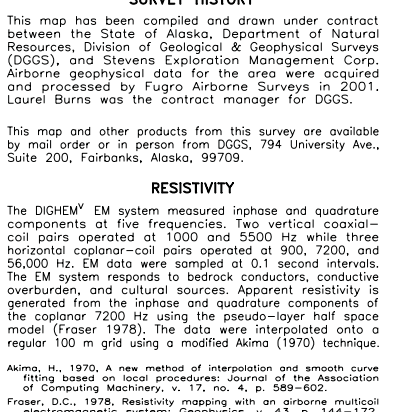




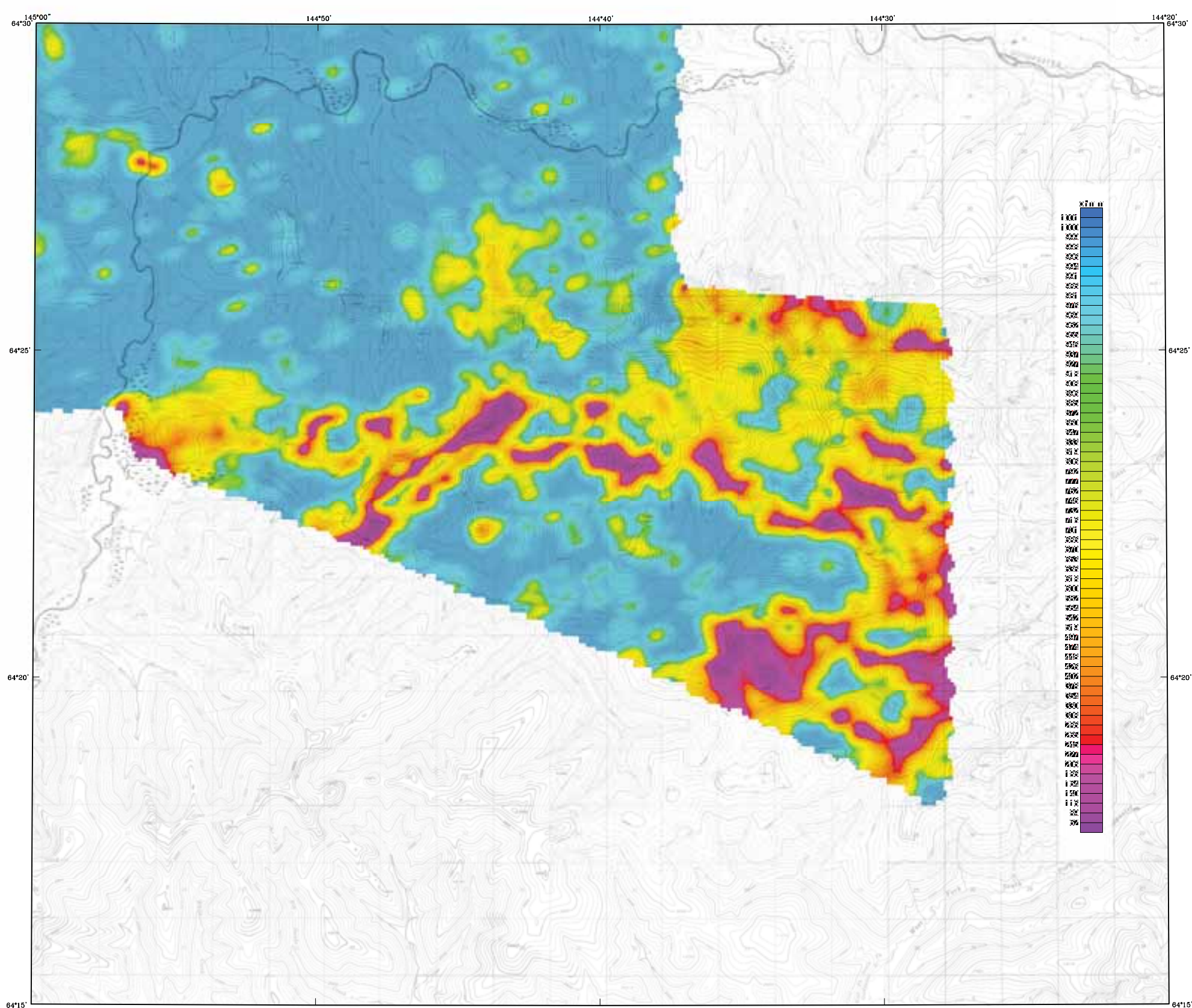

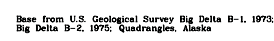
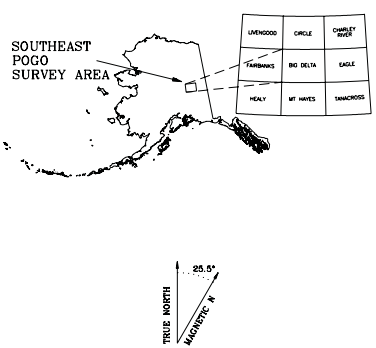

APPROXMATR MEAN

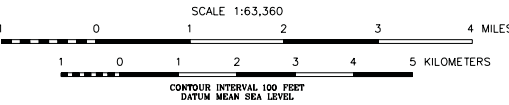

$900 \mathrm{~Hz}$ COPLANAR RESISTIVITY OF THE SOUTHEASTERN EXTENSION OF SALCHA RIVER — POGO SURVEY, GOODPASTER MINING DISTRICT, EAST-CENTRAL ALASKA

PARTS OF BIG DELTA QUADRANGLE

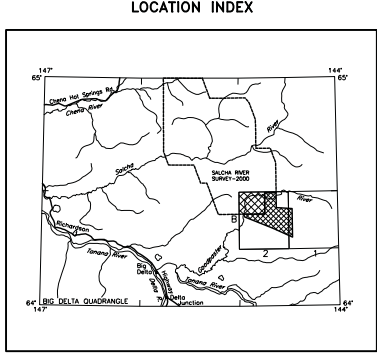

SURVEY HISTORY

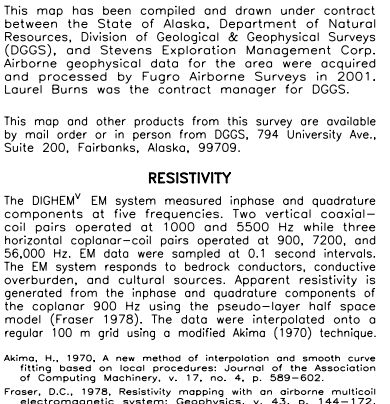




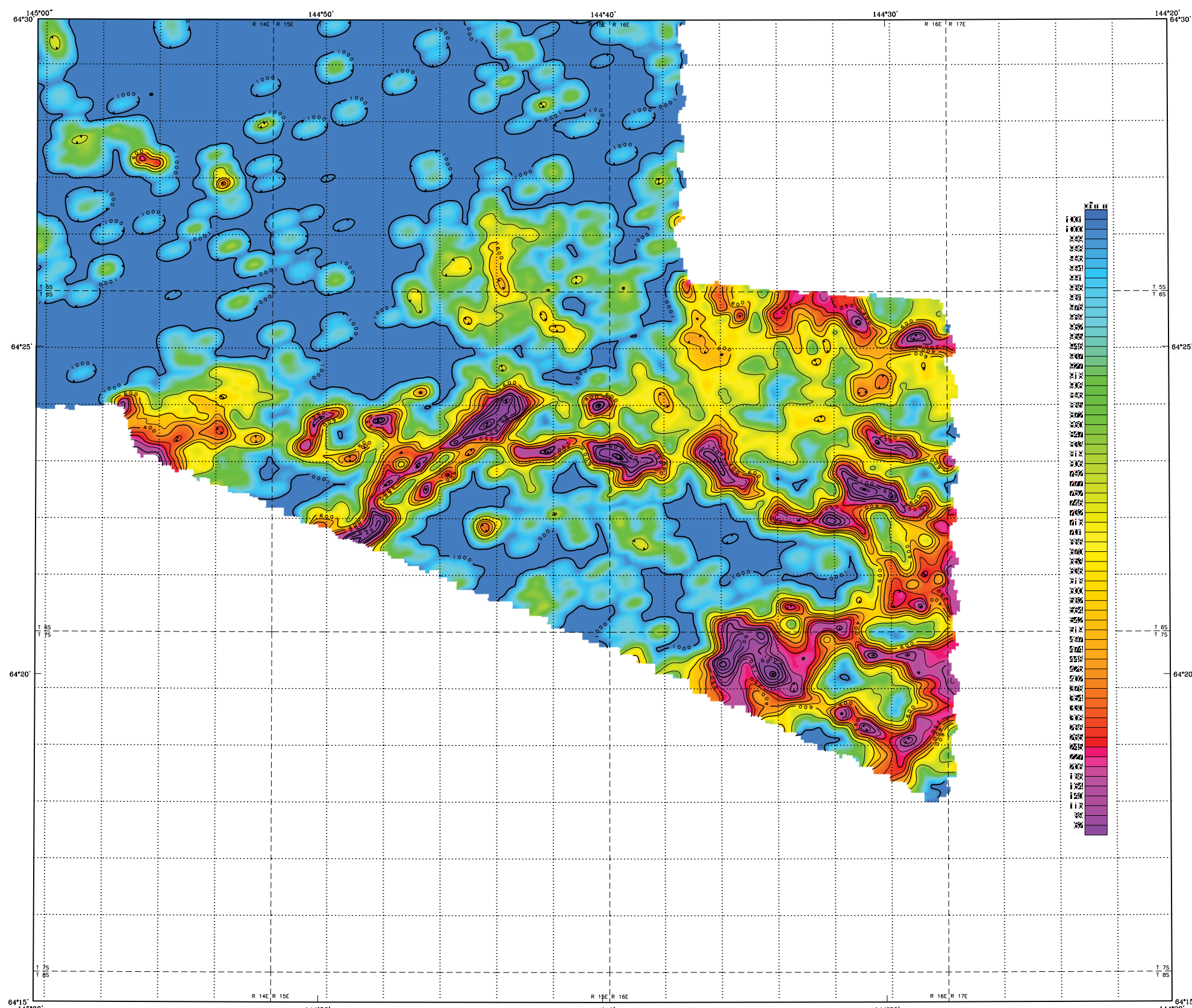

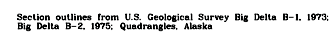

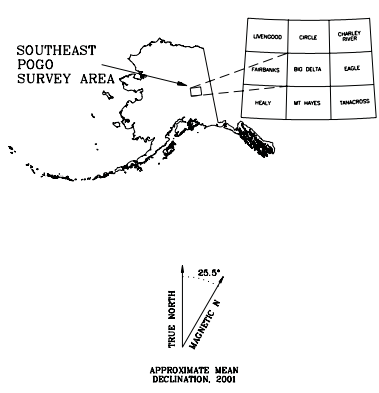

DESCRIPTIVE NOTES

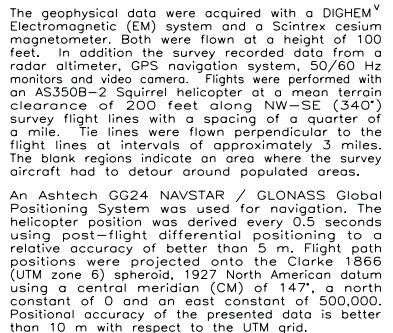

SCALE $1: 63,360$
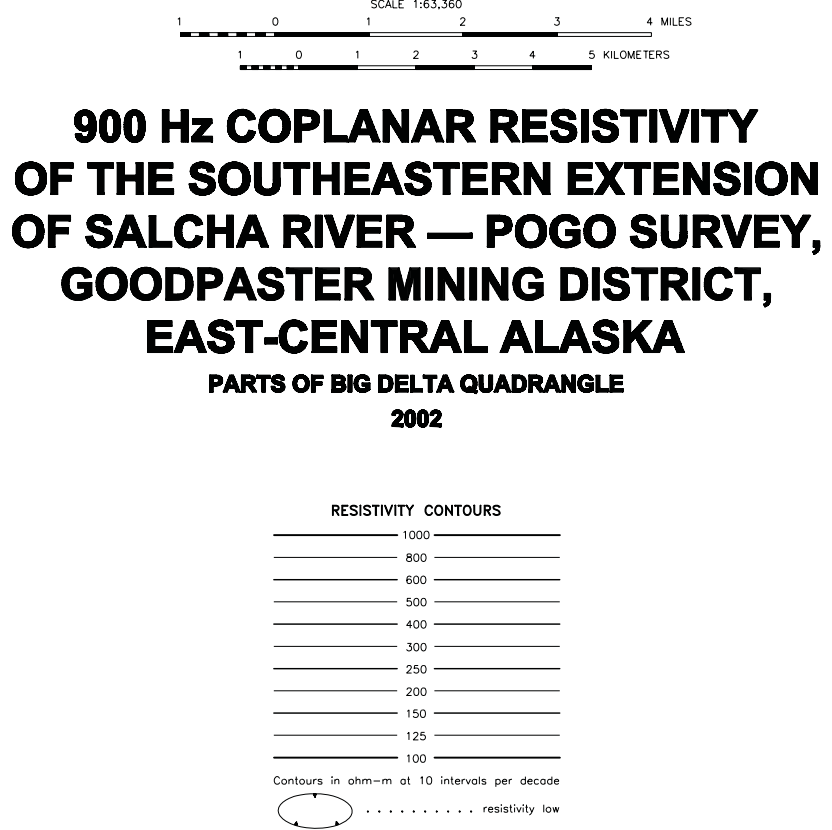

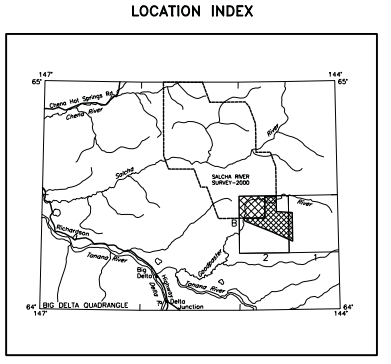

SURVEY HISTORY

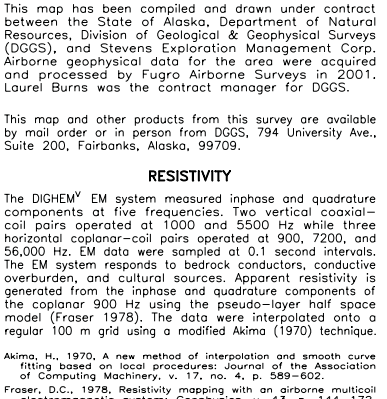




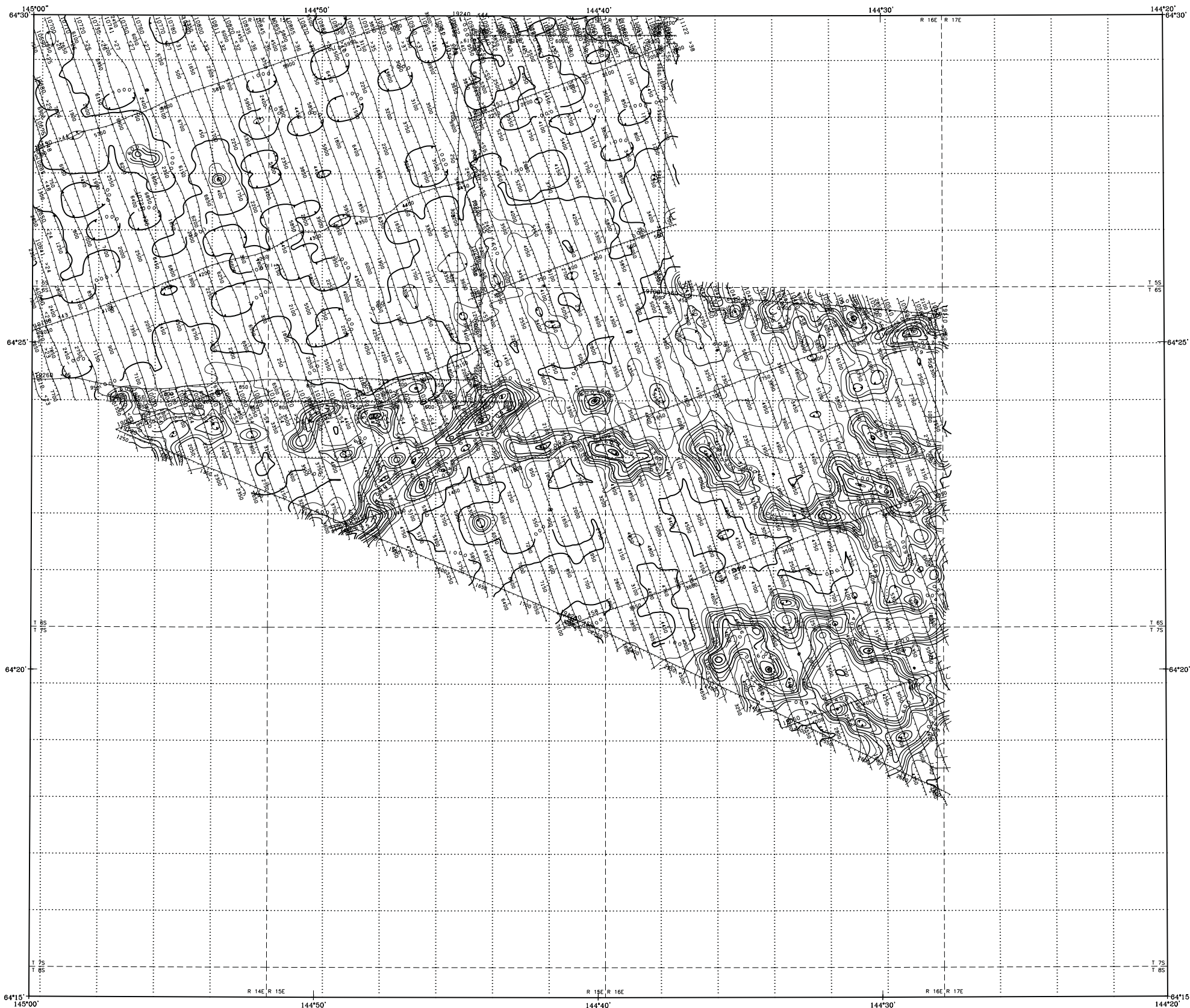

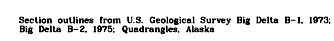

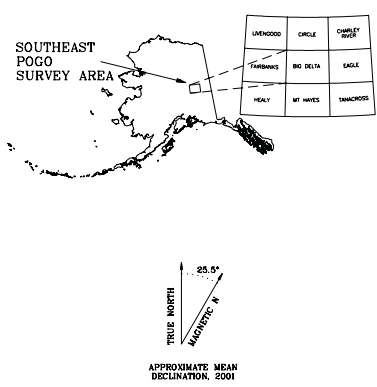

DESCRIPTIVE NOTES

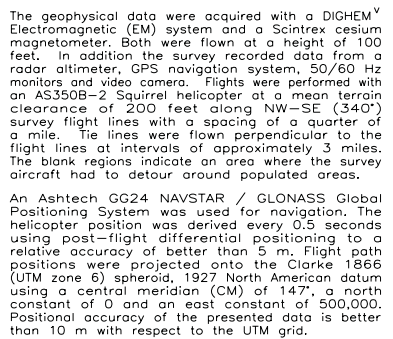

SCALE 1:63,360
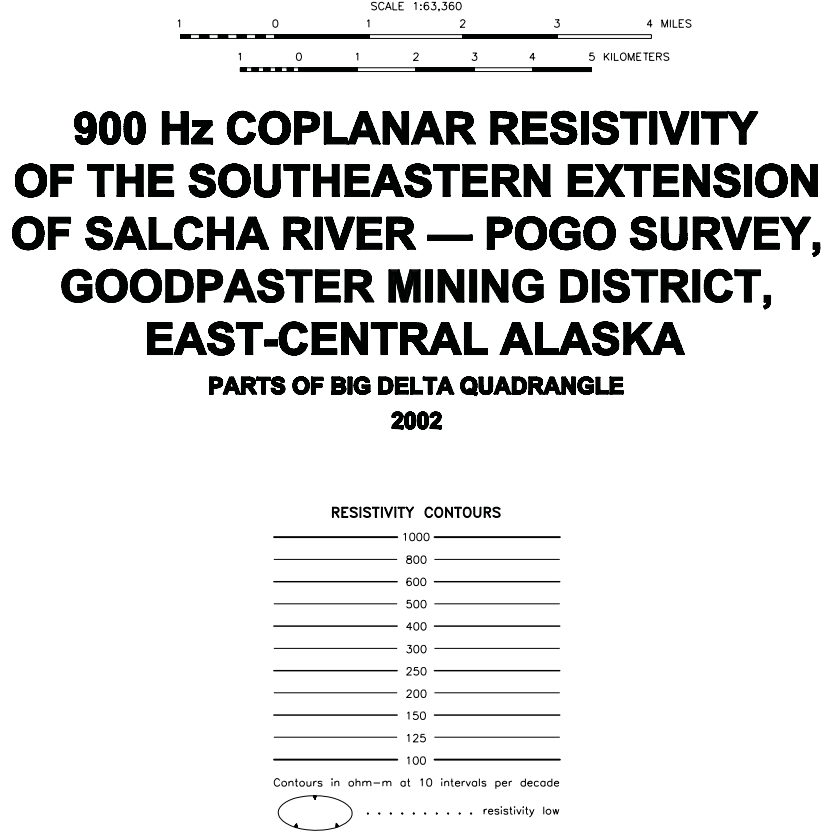

$144^{\circ} 20^{\circ}$

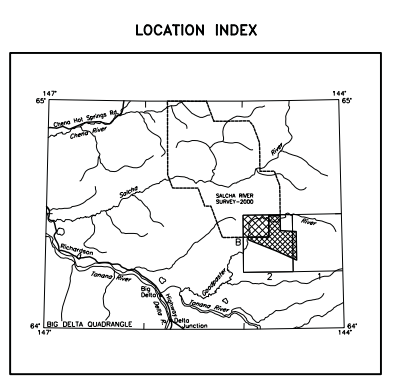

SURVEY HISTORY

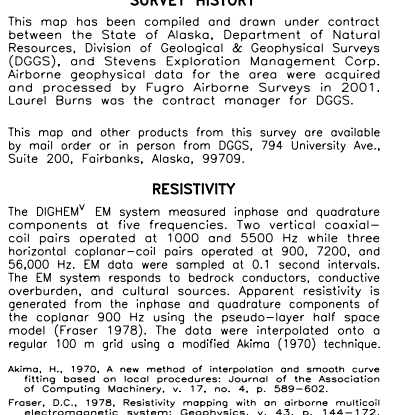




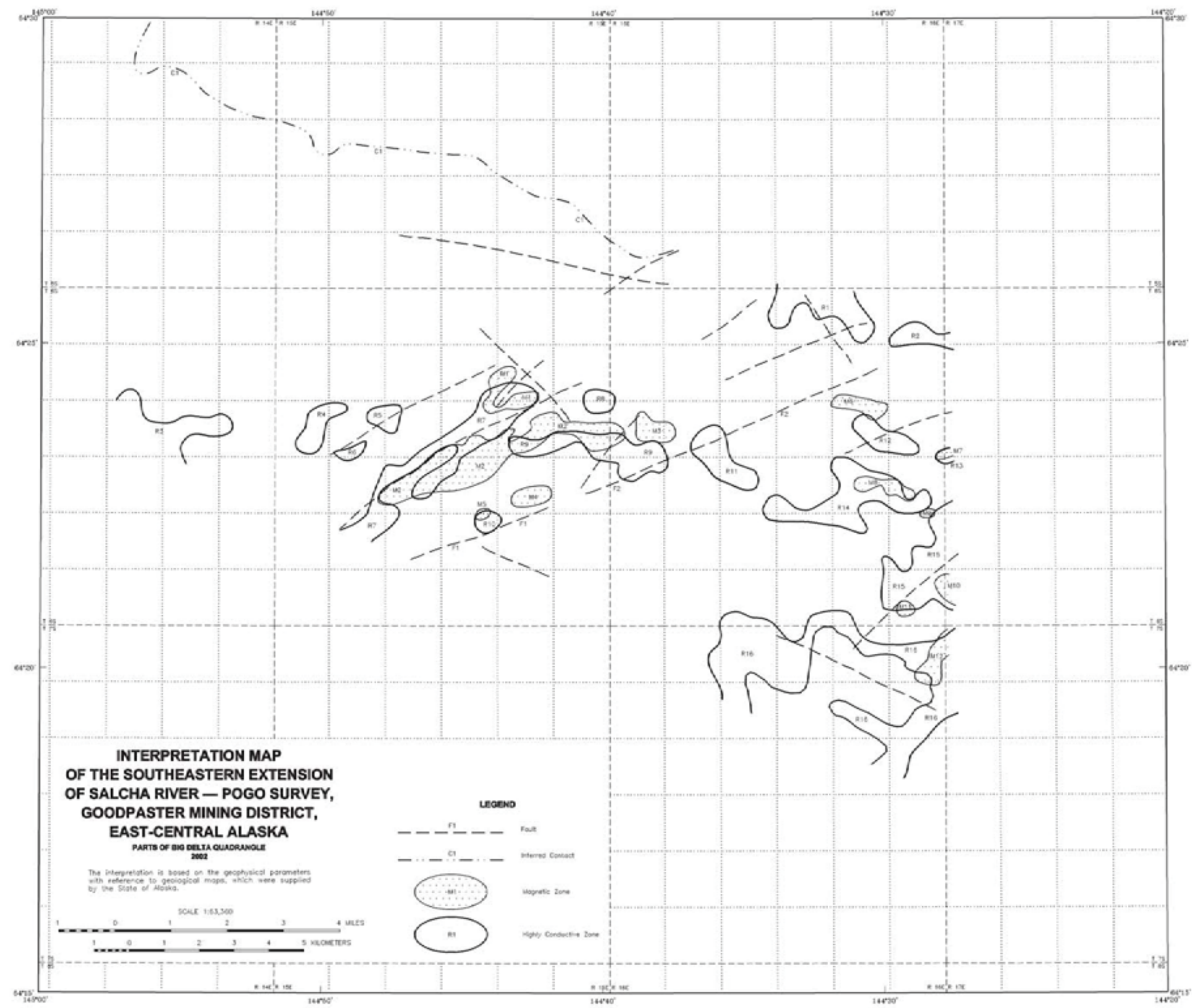




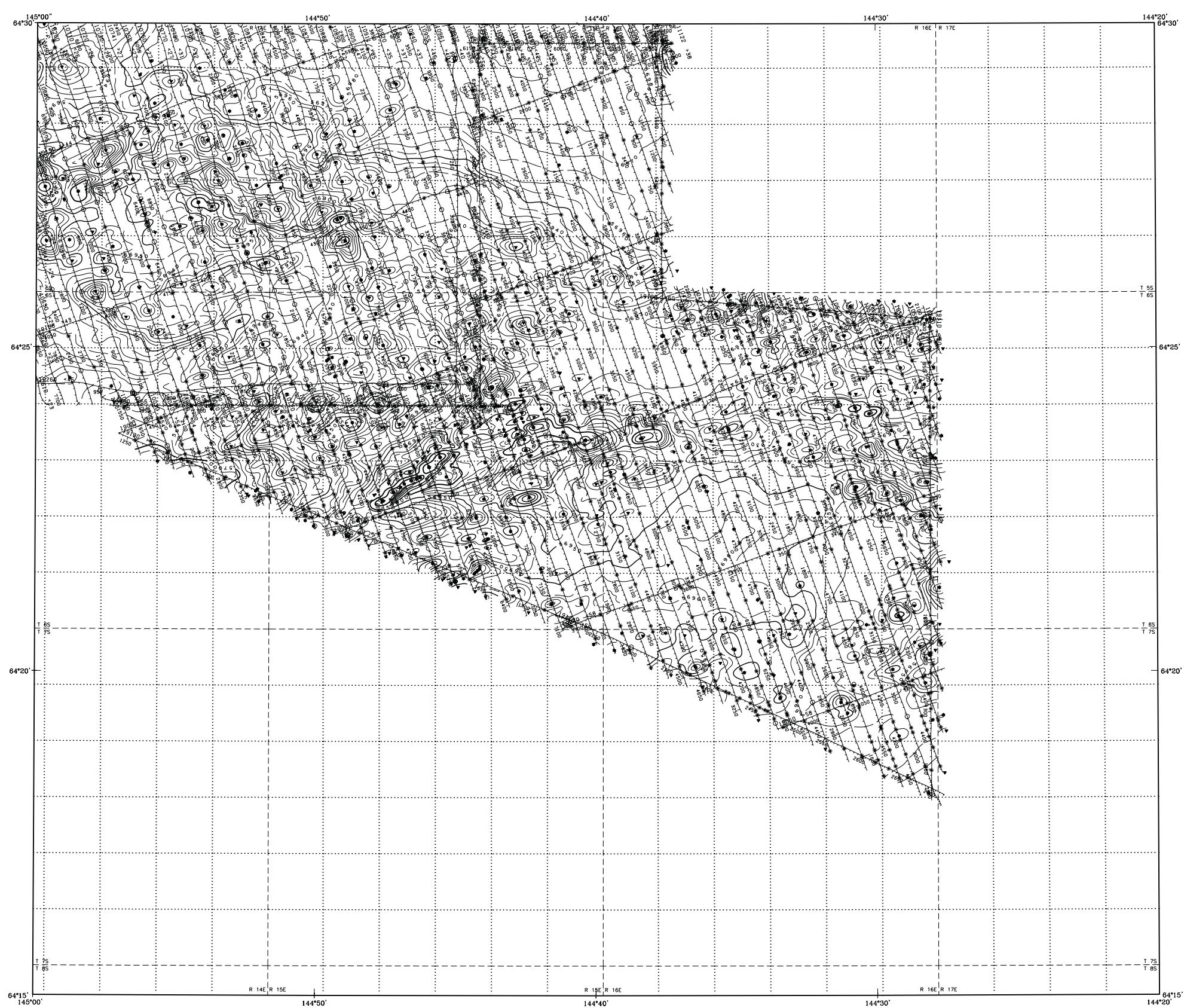

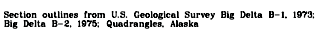

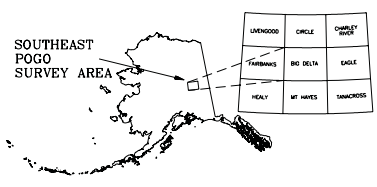

DESCRIPTIVE NOTES

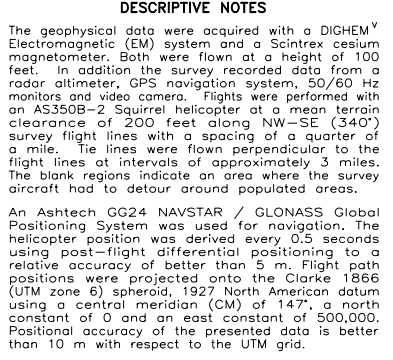

ELECTROMAGNETICS

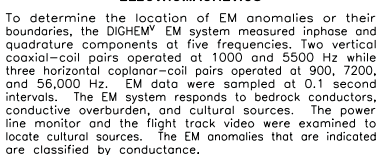

SCALE $1: 63,360$

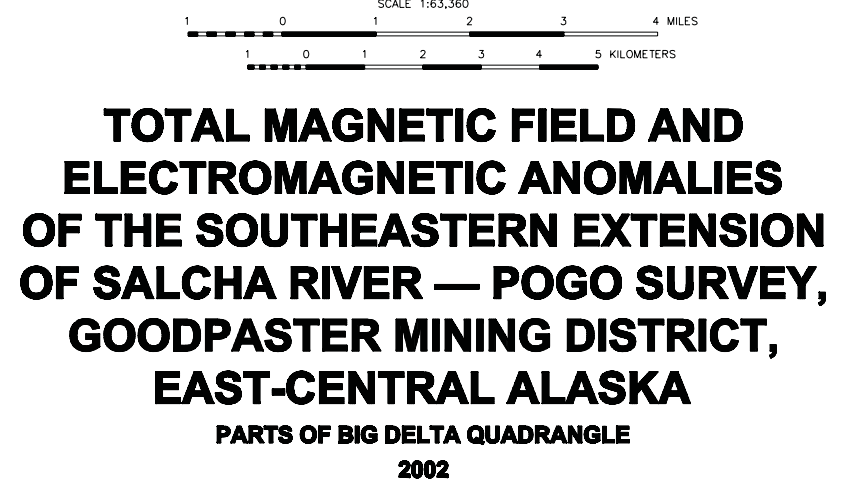

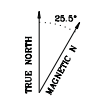

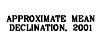

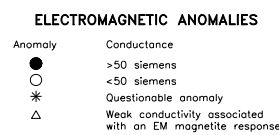

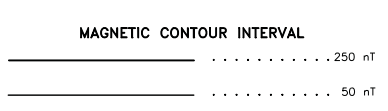

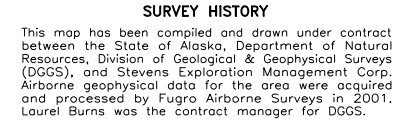

This map and other products from this survey are available
by mail order or in Sy mail order or in person from DGE,

TOTAL MAGNETIC FIELD

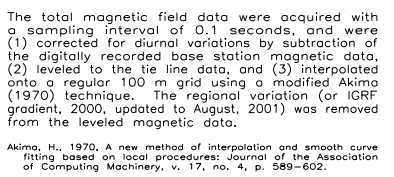




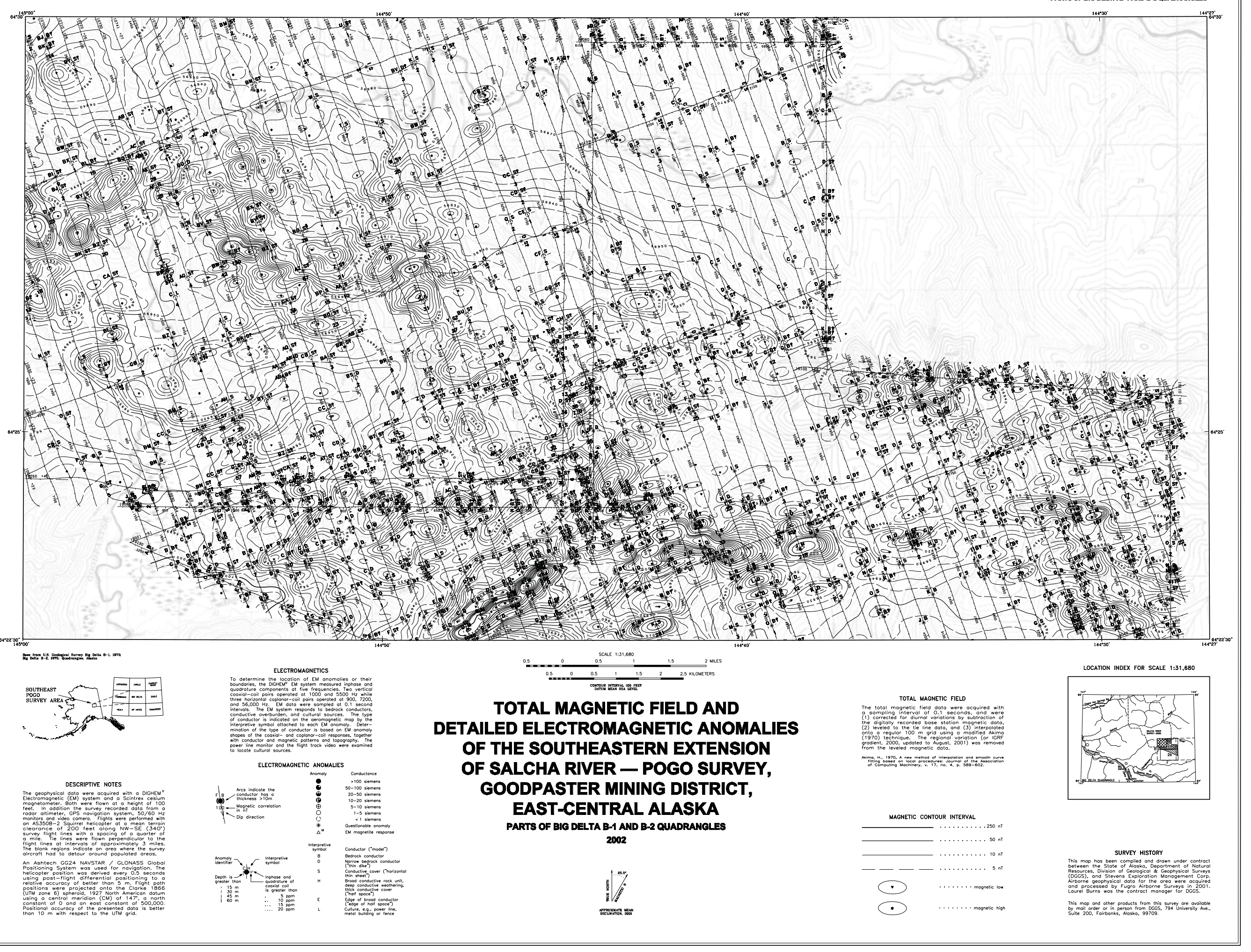




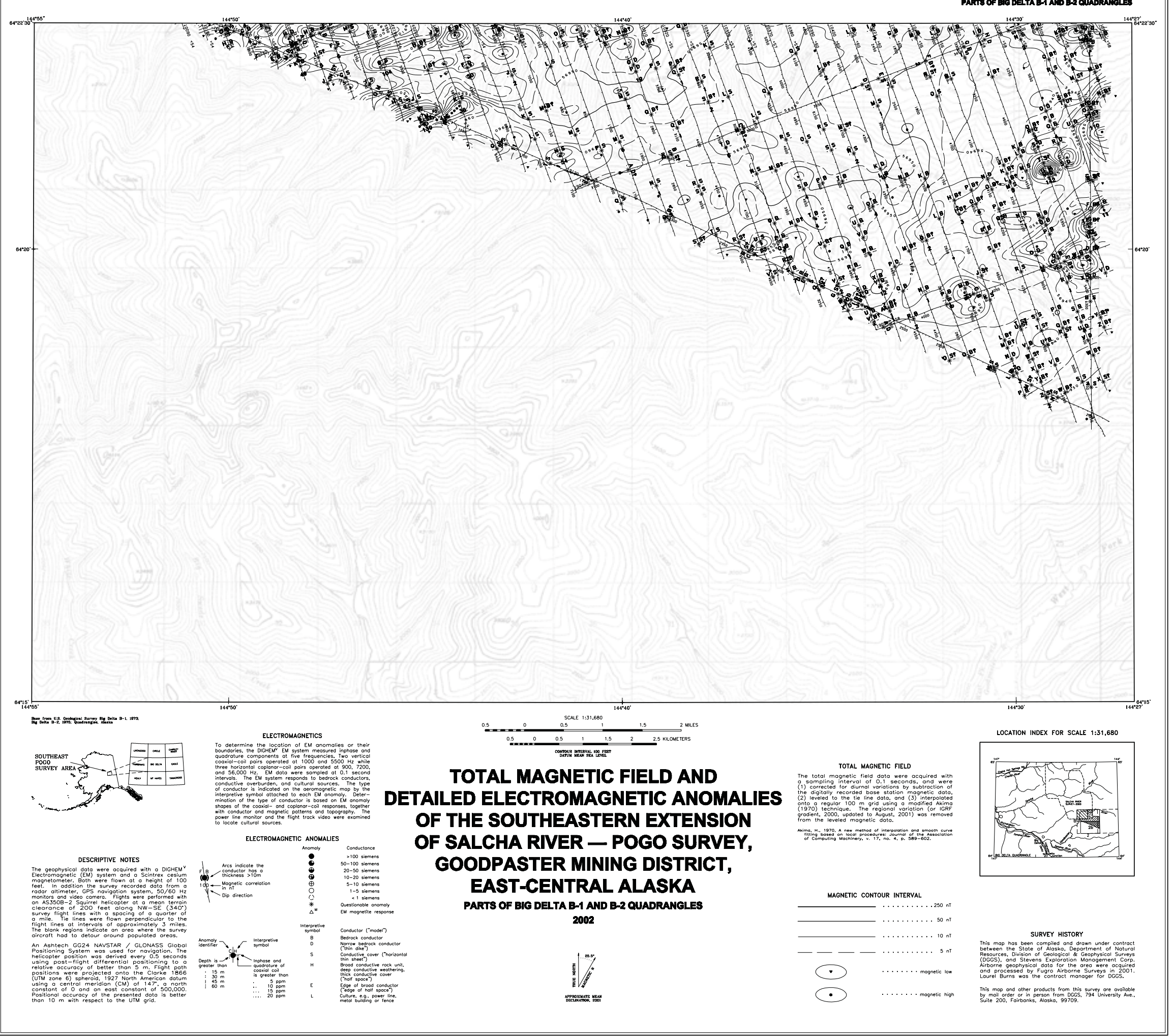

